\title{
Electronic Surface Structures of Coal and Mineral Particles
}

\author{
Final Report \\ Reporting Period Start Date:
}

Reporting Period End Date: March 15, 2001

Principal Authors: M.K. Mazumder (PI), D. A. Lindquist (Co-PI), K. B. Tennal (Co-PI)

Date of Issue: April 2001

Grant ID \#: DE-FG22-96PC96202

M.K. Mazumder (PI), D. A. Lindquist (Co-PI), K. B. Tennal (Co-PI)

Tel: (501) 569-8007, Fax: (501) 569-8020, E-mail: mkmazumder1@ualr.edu

Graduate Students: Steve Trigwell (Ph.D. Student), Steve Farmer (Ph.D. Student), Albert Nutsukpul (M.S. Student), and Alex Biris (Ph.D. Student)

University of Arkansas at Little Rock

Department of Applied Science, ETAS 575

2801 South University Avenue, Little Rock, AR 72204

Program Manager: Dr. Michael Nowak

Final Progress Report

Submitted to

AAD Document Control

U. S. Department of Energy

Pittsburgh Energy Technology Center

P.O. Box 10940, MS 921-143

Pittsburgh, PA 15236-0940

Mailed to

Virginia P. Odoski

U. S. Department of Energy

National Energy Technology Laboratory

Mail Stop 921-126, P.O. Box 10940

Pittsburgh, PA 15236-0940 


\section{DISCLAIMER}

This report was prepared as an account of work sponsored by an agency of the United States Government. Neither the United States Government nor any agency thereof, nor any of their employees, makes any warranty, express or implied, or assumes any legal liability or responsibility for the accuracy, completeness, or usefulness of any information, apparatus, product, or process disclosed, or represents that its use would not infringe privately owned rights. Reference herein to any specific commercial product, process, or service by trade name, trademark, manufacturer, or otherwise does not necessarily constitute or imply its endorsement, recommendation, or favoring by the United States Government or any agency thereof. The views and opinions of authors expressed herein do not necessarily state or reflect those of the United States Government or any agency thereof. 


\section{ABSTRACT}

Surfice science studies rolated to trbocharging and charge separation studies were performed on electrostatic beneficiation of coal. In consrast to other cleaning methods, dectrostatic beneficiation is a dry deaking process requiring no water or subsequent drying Despite these advantages, there is still uncertainty in mplenenting lage-scale commercial electrostatic beneficiation of coal The electronic surface states of coal macerals and minerals are dificult to describe due to heir ehemical complexity and variabinty [1]. The efficiency in separation of mineral particles from organic macerals depends upon these sufface states. Therefore, to further understand and deternine a reason for the bipolar charging observed in coal separation, surface analysis studies using Ultrawiolet Photoelectron Spectroscopy (UPS) and X-ray Photoclectron Spectroscopy (XPS) were performed on coal samples and several materials that are used or considered for use in tribocharging. Electrostatic charging is a surface phenomenon, so the electronic surface states of the paricles, which are infuenced by the envirommental conditions, deternine both polarity and magnitude of tribocharging. UPS was used to measure the work function of the materials as typically used in ambient air. XPS was used to deternine the surface chemistry in the form of contanination and degree of oxidation under the same envirommental conditions.

Mineral bearing coals are those amenable to electrostatic beneficiation. Three types of coal, Minois No. 6, Pitsburgh No. 8, and Kentucky No. 9 were investigated in this study. Pulverized coal powder was tribocharged against copper. Pyritic and other ashes forming minerals in coal powders should charge with a negative polarity from trboelectrilication, and organic macerals should acquire positive charge, according to the 
relative differences in the surface work functions between the material being charged and the charging medium. Different types of minerals exhibit different magnitudes of negative charge and some may also charge positively against copper [2]. Only the mineral sulfur fraction of the total sulfur content is accessible by the electrostatic method since organic sulfur is covalently bound with carbon in macerals. The sizes of mineral constituents in coal range from about 0.1 to $100 \mu \mathrm{m}$, but pyrites in many coals are on the lower end of this scale necessitating fine grinding for their liberation and separation. A ready explanation for coal powder macerals to charge positively by triboelectrification is found in the large numbers of surface carbon free radicals available to release electrons to form aromatic carbocations. There is evidence that these cationic charges are delocalized over several atoms [3]. Only perhaps one in one hundred thousand of the surface atoms is charged during triboelectrification [4], making it difficult to predict charging levels since the data depends upon the surface chemical species involved in charging. Based on the high electron affinity of oxygen atoms, oxidation is expected to decrease the extent of a coal particle to charge positively. Also, ion transfer may contribute to the increasingly negative charging character of oxidized coal carbons. A variety of oxidized surface functional groups may influence charge properties. For example, carboxylic acid functions can lose protons to form carboxylate anions. The samples of coal investigated in this study showed differing degrees of beneficiation, consistent with a more extensively oxidized Illinois No. 6 coal sample relative to that of Pittsburgh No. 8. Even though oxygen in air is deleterious to coal stored prior to beneficiation, other gases might favorably influence charge properties. To this end, coal exposed to vapors of acetone, ammonia, and sulfur dioxide also were beneficiated and analyzed in this study. 


\section{TABLE OF CONTENTS}

Abstract 3-4

Executive Summary

Introduction $\quad 8-10$

Experimental Methods, Results, and Discussion $\quad 10-42$

Conclusion $\quad 42-44$

References $\quad 44-45$ 


\section{LIST OF FIGURES}

Figure 1: Schematic of a static charger showing the airflow $Q$ (dashed line) and inside diameter $\mathrm{Dj}$

Figure 2: Variation of the particle cut-off diameter with flowrate and mixer tube diameter Figure 3: Schematic showing the basic elements for triboelectrification and electrostatic separation.

Figure 4: DRIFT spectra of (a) Pittsburgh No. 8 fresh feed coal, (b) processed No. 8 coal from the negative plate, and (c) processed No. 8 coal from the positive plate

Figure 5: Charge to Mass Ratios for Pittsburgh No. 8 clean and refuse coal powders Figure 6: Average total sulfur content of feed and beneficiated Pittsburgh No. 8 coal for two size classifications.

Figure 7: Average total sulfur content of Pittsburgh No. 8 coal powders processed after 24 hours of air exposure show similar beneficiation as that of fresh ground powder.

Figure 8: Effects of oxidation on Illinois No. 6 coal showing total sulfur, sulfate, and pyritic sulfur content for two size classifications.

Figure 9: Ash percentages of Pittsburgh No. 8 and oxidized Illinois No. 6 coal powder showing poor beneficiation of oxidized Illinois No. 6 coal.

Figure 10. Results of $\mathrm{SO}_{2}$ conditioning agent experiments with Illinois No. 6 powder showing control before exposure (a) and after conditioning (b).

Figure 11: Results of conditioning agent experiments with Illinois No. 6 powders showing control before exposure (a), acetone conditioning (b), and ammonia conditioning (c).

Figure 12: First pass ash and total sulfur values (a), and second pass ash and sulfur values for clean (b) and refuse (c) oxidized Illinois No. 6 powder.

Figure 13: First pass ash and total sulfur values (a), and second pass ash and sulfur values for clean (b) and refuse (c) oxidized Pittsburgh No. 8 powder.

Figure 14: Optical micrograph of the cross-sectioned Pittsburgh No. 8 specimen showing the points of analysis.

Figure 15: XPS data for Illinois No. 6 coal sample showing: (a) and (b) C1s, (c) and (d) $\mathrm{S} 2 \mathrm{p}$, and (e) and (f) Fe2p peaks for the rough and smooth areas.

\section{LIST OF TABLES}

Table 1: Petrographic analyses of beneficiated Illinois No. 6 coal powders.

Table 2: Work function measurements on cross-sectioned coal samples in air.

Table 3: Work function measurements on various materials in air

Table 4: XPS data for Pittsburgh No. 8 coal specimen.

Table 5: XPS data for specimens analyzed in the as-received condition. 


\section{EXECUTIVE SUMMARY}

In contrast to other cleaning methods, electrostatic beneficiation of coal for industrial use is a dry cleaning process requiring no water or subsequent drying. Despite these advantages, there is still uncertainty in implementing large-scale commercial electrostatic beneficiation of coal. The electronic surface states of coal macerals and minerals are difficult to describe due to their chemical complexity and variability [1]. The efficiency in separation of mineral particles from organic macerals depends upon these surface states. Therefore, to further understand and determine a reason for the bipolar charging observed in coal separation, surface analysis studies using Ultra-violet Photoelectron Spectroscopy (UPS) and X-ray Photoelectron Spectroscopy (XPS) were performed on coal samples and several materials that are used or considered for use in tribocharging. Electrostatic charging is a surface phenomenon, so the electronic surface states of the particles, which are influenced by the environmental conditions, determine both polarity and magnitude of tribocharging. UPS was used to measure the work function of the materials as typically used in ambient air. XPS was used to determine the surface chemistry in the form of contamination and degree of oxidation under the same environmental conditions. 


\section{INTRODUCTION}

Studies are warranted in order to improve electrostatic cleaning of coal, which removes pyrites and other minerals. In contrast to other cleaning methods, electrostatic beneficiation is a dry cleaning process requiring no water or subsequent drying. Despite the apparent advantages, there is still uncertainty in implementing large-scale commercial electrostatic beneficiation of coal. The electronic surface states of coal macerals and minerals are difficult to describe because of their chemical complexity and variability [1]. Although the triboelectrostatic properties of various substances are well documented, the charging and separation mechanisms involved remain poorly understood.

Mineral bearing coals are those amenable to electrostatic beneficiation. Three types of coal, Illinois No. 6, Pittsburgh No. 8, and Kentucky No. 9 were investigated in this study. Pulverized coal powder was tribocharged against copper. Pyritic and other ashes forming minerals in coal powders should charge with a negative polarity from triboelectrification, and organic macerals should acquire positive charge, according to the relative differences in the surface work functions between the material being charged and the charging medium. Different types of minerals exhibit different magnitudes of negative charge and some may also charge positively against copper [2]. Only the mineral sulfur fraction of the total sulfur content is accessible by the electrostatic method since organic sulfur is covalently bound with carbon in macerals. The sizes of mineral constituents in coal range from about 0.1 to $100 \mu \mathrm{m}$, but pyrites in many coals are on the lower end of this scale necessitating fine grinding for their liberation and separation. A ready explanation for coal powder macerals to charge positively by triboelectrification is found in the large numbers of surface carbon free radicals available to release electrons to form aromatic 
carbocations. There is evidence that these cationic charges are delocalized over several atoms [3]. Only perhaps one in one hundred thousand of the surface atoms is charged during triboelectrification [4], making it difficult to predict charging levels since the data depends upon the surface chemical species involved in charging. Based on the high electron affinity of oxygen atoms, oxidation is expected to decrease the extent of a coal particle to charge positively. Also, ion transfer may contribute to the increasingly negative charging character of oxidized coal carbons. A variety of oxidized surface functional groups may influence charge properties. For example, carboxylic acid functions can lose protons to form carboxylate anions. The samples of coal investigated in this study showed differing degrees of beneficiation, consistent with a more extensively oxidized Illinois No. 6 coal sample relative to that of Pittsburgh No. 8. Even though oxygen in air is deleterious to coal stored prior to beneficiation, other gases might favorably influence charge properties. To this end, coal exposed to vapors of acetone, ammonia, and sulfur dioxide also were beneficiated and analyzed in this study.

The efficiency in separation of mineral particles from organic macerals depends upon the efficiency of charging and subsequent separation. In order to further understand and determine a reason for the bipolar charging observed in coal separation, surface analysis studies using Ultra-violet Photoelectron Spectroscopy (UPS) and X-ray Photoelectron Spectroscopy (XPS) were performed on coal samples and several materials that are used or considered for use in tribocharging. Electrostatic charging is a surface phenomenon. Therefore the electronic surface states of the particles, which are influenced by the environmental conditions, determine both polarity and magnitude of tribocharging. UPS was used to measure the work function of the materials as typically used in ambient 
air. XPS was used to determine the surface chemistry in the form of contamination and degree of oxidation under the same environmental conditions.

\section{EXPERIMENTAL METHODS, RESULTS, AND DISCUSSION}

\section{A. EXPERIMENTAL METHODS}

\section{Sample preparation}

Samples of Illinois No. 6, Pittsburgh No. 8, and Kentucky No. 9 coal were used in this study. Samples of copper from an as-used Koflo static mixer, Polytetrafluroethylene (PTFE) which is also used as a tribocharging material, concentrated vitrinite from a double pass separation, pure pyrite, and graphite powder (as a carbon standard) were analyzed by UPS and XPS in the as-received condition.

\subsection{Grinding and Classification}

Illinois No.6 and Pittsburgh No. 8 coal were finely ground in either ambient air, or alternatively in a nitrogen $\left(\mathrm{N}_{2}\right)$ atmosphere inside a glove bag using a Micro-Hammer Cutter Mill (Gilson Company Inc., Model LC-5). Size classified powders were prepared by mechanically vibrating the powders for a minimum of 20 minutes through a stack of progressively finer screen sieves $(150,105,75,45 \mu \mathrm{m})$. Typically, only a third of the quantity of sub- $45 \mu \mathrm{m}$ powder went through the bottom sieve in the second 10 minutes as accumulated during the first 10 minutes of sieving. After 20 minutes each fraction was assumed to be largely depleted of sub sized powder. 


\subsection{Cross-sectioning of coal nuggets}

Nuggets of the Illinois, Pittsburgh, and Kentucky coal were cross-sectioned in two. A slice of approximately $5 \mathrm{~mm}$ in thickness from the flat face was cut from one half of each nugget. They were sectioned using a low-speed cutting saw (Buehler Inc, ISOMET model) and a precision diamond tipped cutting blade. Before cutting the coal nuggets, the blade was ultrasonically cleaned in acetone, methanol, and iso-propanol. The blade was run at a relatively low speed of 100 revolutions per minute to minimize heat build up but without any cutting fluid to avoid contamination. XPS analysis of practice specimens had shown no contamination from the blade. The coal specimens were wrapped in clean aluminum foil to prevent the exposed surface from contamination. The foil was removed prior to analysis.

\section{Tribocharging of pulverized coal}

A schematic of a copper static mixer (Koflo, Inc.) is shown in Figure 1. The mixer consists of a series of copper spiral vanes within a steel tube. The coal particles are injected into the air flow (dashed line) and impacted on the internal plates of the static mixer (solid lines) as the gas flowed through the mixer changing direction to move around the internal plates. Two conditions are required for powder tribocharging: 1) inertial impaction between powder and charger; 2) the materials of the powder and charger should be far enough apart in the triboelectric series so they have significantly different work functions. The impaction efficiency is related to the particle diameter $\left(d_{p}\right)$ and the inside diameter $(\mathrm{Dj})$ of the static charger by the following equation:

$$
\mathrm{d}_{50}\left(\mathrm{C}_{\mathrm{c}}\right)^{1 / 2}=\left[9 \pi \eta \mathrm{D}^{3}\left(\mathrm{Stk}_{50}\right)\right]^{1 / 2} /\left(4 \rho_{\mathrm{p}} \mathrm{Q}\right)^{1 / 2}
$$




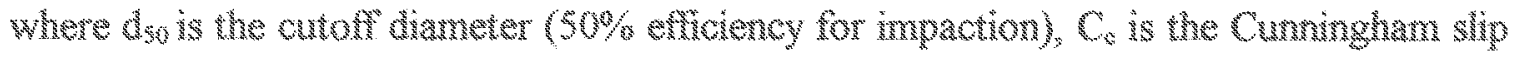
correction ractor, nis the viscosity of gas, $\$ 4 k$ is the Stokes Number for $50 \%$ impaction exciency, $\rho_{p}$ is the particle densty, Dj is the Je dameter, and $Q$ is the howrote of ar.

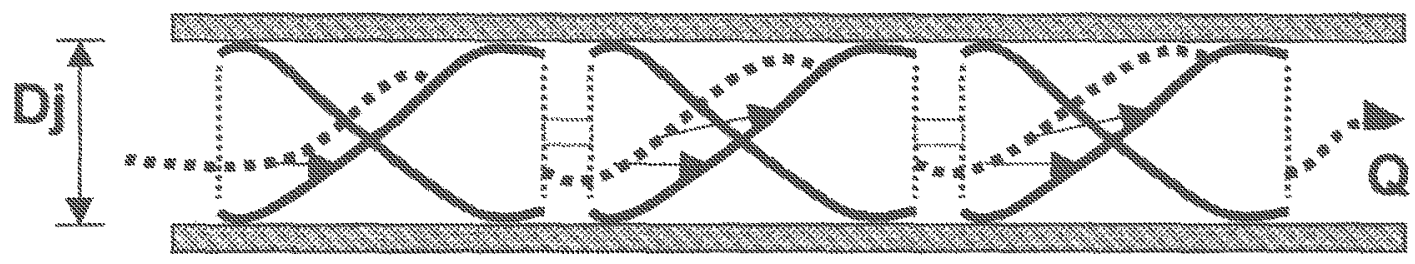

Mgure 1: Schematic of a state charger showing the ambow Q (dashed line) and inside diamerer Dj

From this equation it can be observed that the onton dameter is directy propontona to the state wher twe diameter $D_{3}$ and inversely propontiond to the lowrate

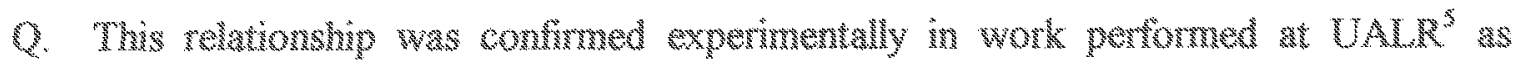
presented in Prgure 2

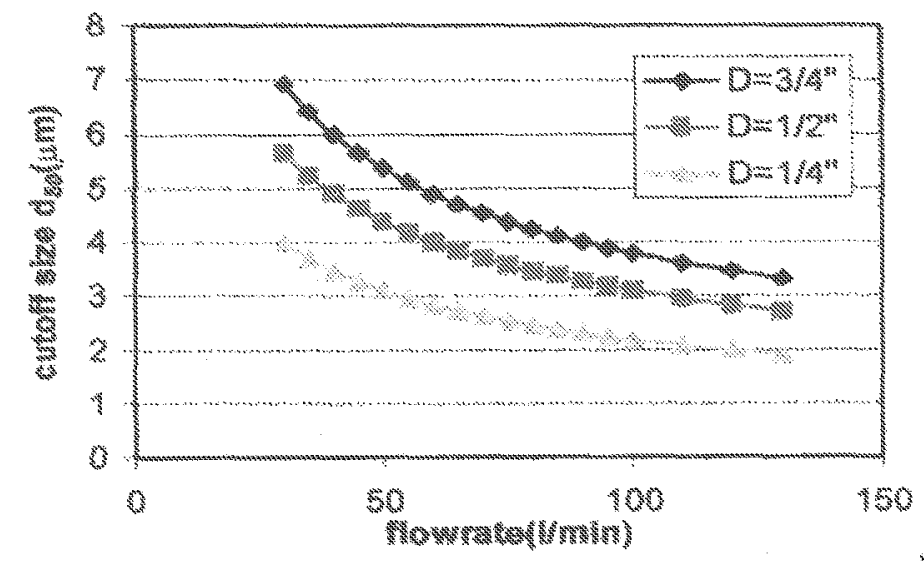

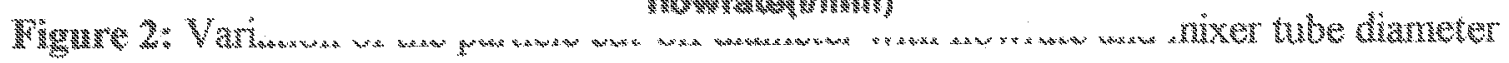

\section{Separwor Design and Operwhon}


A schematic drawing of the electrostatic separator is shown in Figure 3. Powdered coal was supplied to a powder pump through a Fritsch vibratory feeder (Gilson Company Inc., Model LCA-129). Pressurized nitrogen was used to operate the powder pump which controlled the flow of powder at a desired mass flow rate. The coal powder was charged by a copper static mixer of internal diameter $1.6 \mathrm{~cm}$ and length $30 \mathrm{~cm}$. The bipolarly charged powder then entered into the electrostatic separator. The velocity of air in the static mixer was approximately $10 \mathrm{~ms}^{-1}$ while the air velocity at the entrance of the separator was approximately $0.5 \mathrm{~ms}^{-1}$. The separator consisted of two electrically conducting plates $30 \mathrm{~cm}$ wide by $90 \mathrm{~cm}$ long, spaced $25 \mathrm{~cm}$ apart at the top and angles such that the spacing between them decreased linearly to $10 \mathrm{~cm}$ at the bottom just above the filter. The two electrodes were connected to two high voltage power supplies (Glassman High Voltage Inc., Models MJ20P0700-11 and MJ20N0700-11): one was positive from 0 to $20 \mathrm{kV}$, and the other negative from 0 to $-20 \mathrm{kV}$. In general, a $15 \mathrm{kV}$ voltage was applied to the collection plates of the separator during each experiment. The electric field was higher at the bottom of the plates than at the top because of the geometry of the separator. The V-shaped walls were chosen to reduce air turbulence in the separator. Room air flowed into the separator in a sheath around the static mixer having passed first through a flow straightener consisting of a $2.5 \mathrm{~cm}$ layer of open foam atop a $10 \mathrm{~cm}$ thick plastic honeycomb with cell diameters of $0.65 \mathrm{~cm}$. Inside the separator, the particles that were highly charged deposited near the top of the plates and the particles that have lower charge or lower electrical mobility deposited nearer the bottom since they required higher field and longer path for separation. 


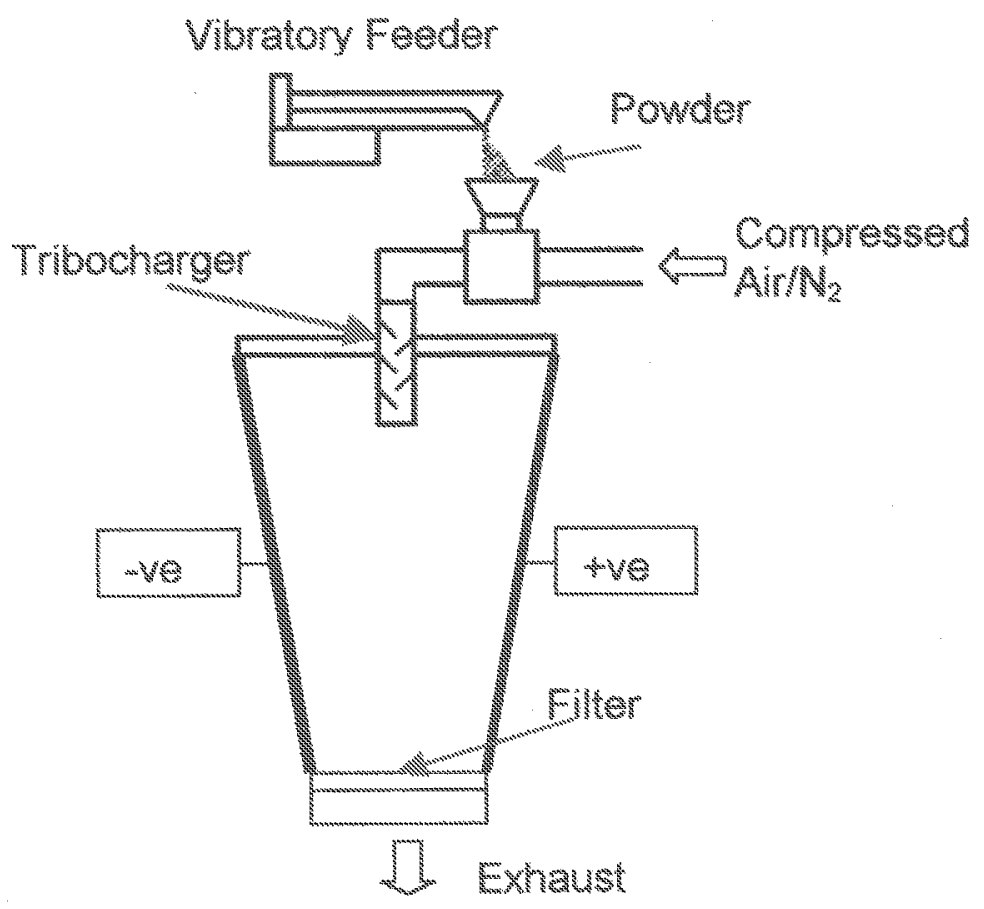

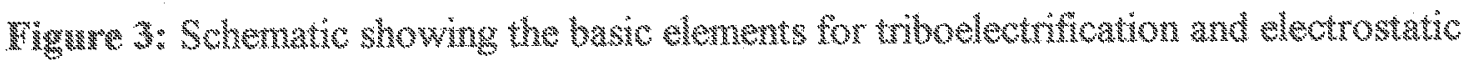
separation.

For Reynolds manber less than one, he motion of the particle con be asmuned to be in the Stokes regine where the rnent forces are neglgible, and riscons foros dominate. Aswming the smple case of laminax How of ar berween two paralle plates and neglecting the mhence of the charged oloud, the vertod downward velocily (U, dre bo

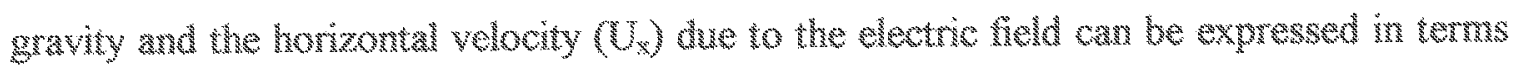
frbe $x$ and y coorinates of the particles;

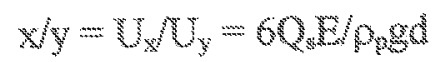


where $Q_{s}$ is the particle surface charge density, $E$ is the electric field applied between the plates, $\rho_{p}$ is the density of the particle, $g$ is the acceleration due to gravity, and $d$ is the diameter of the particle.

When the particle is carried along with the air downwards, the velocity of air has to be added to the vertical velocity of the particle and the equation gets modified to:

$$
\mathrm{x} / \mathrm{y}=\mathrm{U}_{\mathrm{z}} / \mathrm{U}_{\mathrm{y}}+\mathrm{U}_{\mathrm{x}}==6 \mathrm{Q}_{\mathrm{s}} \mathrm{E} / \rho_{\mathrm{p}} \mathrm{gd}+18 \mathrm{U}_{\mathrm{a}} \eta / \mathrm{d}
$$

where Ua is the velocity of air at the inlet of the separator.

Equation (3) suggests that if the charge on the particle is proportional to the surface area of the particle, then smaller diameter particles are difficult to collect since their vertical motion in the separator is influenced more by the downward velocity of air. Very large particles are also difficult to collect since charge/mass is inversely proportional to the diameter. Thus it is particles of an intermediate size which are most easily collected in the separator.

\section{Environmental Conditions}

Environmental conditions were of interest due to the high chemical reactivity of coal powder surfaces and its effects on beneficiation. To augment air exposure, freshly ground coal powders were exposed to air in open containers for 24 hours before beneficiation. Alternatively to minimize the effects of air exposure, powders were ground in an $\mathrm{N}_{2}$ atmosphere in a glove bag and beneficiated in $\mathrm{N}_{2}$ by fitting the inlet of the electrostatic separator with an $\mathrm{N}_{2}$ filled glove bag. The effects of three potential conditioning agents:

ammonia gas, sulfur dioxide $\left(\mathrm{SO}_{2}\right)$, and acetone also were tested as follows. For $\mathrm{SO}_{2}$ 
exposure Illinois No. 6 coal was finely ground and sieved to -200 mesh $(<75 \mu \mathrm{m})$ powder in a glove bag under nitrogen atmosphere. One hundred grams of the powdered coal were reserved in a sealed container as a control sample and an equal amount of powdered coal was placed in a stoppered flask equipped with side arms for tubing to allow gas flow through the flask. The coal then was exposed to $\mathrm{SO}_{2}$ gas in an argon environment. $\mathrm{SO}_{2}$ was generated by the reaction of copper powder with concentrated sulfuric acid in a heated flask. Argon was purged over the mixture to carry the gas through a glass tube cooled in ice water in order to condense trace water vapor. The cooled gas then passed through the coal flask with side arms. The coal sample inside the flask was shaken during the entire 15-minutes of exposure. Next, the flask of $\mathrm{SO}_{2}$ exposed coal was processed through the electrostatic separator in $\mathrm{N}_{2}$ atmosphere. The other half of the coal sample, which had not been exposed to $\mathrm{SO}_{2}$, was beneficiated similarly. The results were then compared. Similarly, control and test samples were also employed for both the acetone and ammonia conditioning agent experiments. To prepare acetone-conditioned coal, $\mathrm{N}_{2}$ gas was bubbled through acetone and the vapors directed over coal powder shaken in a side arm equipped flask for ten minutes. A similar exposure time of anhydrous ammonia vapor from a cylinder was used to make ammonia conditioned coal powder. These conditioning agents were examined for improving the efficiency of beneficiation.

\section{Chemical Analysis of Beneficiation}

Powder samples collected as clean coal on the negative electrode and as refuse on the positive electrode were analyzed for their chemical constituents and mineral content. Quantitative determination of (1) total sulfur content, (2) pyritic and sulfate sulfur content, 
(3) ash content, and (4) moisture content of feed, beneficiated, and refuse coals were determined according to ASTM standard methods: D3177-84, D2492-84, D3174-89, and D3173-87 respectively. Duplicate analyses were performed on each sample. Triplicate gravimetric and total sulfur analyses were conducted on samples from the acetone, ammonia, and sulfur dioxide conditioning experiments.

Petrographic analysis of powders was used to determine the charging characteristics of the various coal macerals for electrostatic beneficiation. Samples of clean and refuse coal powders deposited on the negative and positive plates of the separator were collected and prepared for petrographic analysis by casting the powders in epoxy resin and forming the bonded material as a flat slab by polishing with a wateralumina slurry. The polished slabs were then mounted on a microscope slide for petrographic analysis. A minimum of 800 particles from both clean and refuse powder samples were individually identified and classified by maceral type (i.e. vitrinite, liptinite, or inertinite) using optical microscopy. If the particle was composed of more than one maceral type, the particle was classified according to the dominant maceral component present in the particle. Similarly, particles readily identifiable as minerals or macerals in which entrained minerals could be clearly seen were also classified. The petrographic analysis showed the physical and morphological composition of the particles separated in the charge separator.

Diffuse reflectance infrared Fourier transform (DRIFT) spectroscopy of feed and electrostatically separated coal powders was used to monitor composition differences with respect to organic functional group vibrational frequencies. Samples were prepared as a 2 wt\% mixture of coal with finely ground dry $\mathrm{KBr}$. The DRIFT spectra were obtained using 
a Nicolet Instrument model Magna-IR 500 Series II spectrometer and an International Crystal Laboratories DRIFT cell. The spectral outputs were adjusted for scattering effects using the Kubelka-Munk algorithm available with the instrument software.

\section{Surface Analytical Techniques}

\subsection{XPSMeasurements}

The XPS data were obtained on a PHI Quantum 2000 ESCA Spectrometer using a focussed monochromatic $\mathrm{Al} \mathrm{K \alpha}(\mathrm{h} v=1486.7 \mathrm{eV})$ x-ray source. The x-ray beam used was a $100 \mathrm{~W}, 100 \mu \mathrm{m}$ diameter beam and was rastered over a $1.5 \mathrm{~mm}$ by $0.2 \mathrm{~mm}$ area. The survey scans were collected using a pass energy of $117.4 \mathrm{eV}$ producing a FWHM of better than $1.6 \mathrm{eV}$ for the $\mathrm{Ag} 3 \mathrm{~d} 5 / 2$ peak. The high energy resolution data were collected using a pass energy of $23.5 \mathrm{eV}$, producing a FWHM of better than $0.75 \mathrm{eV}$ for the $\mathrm{Ag} 3 \mathrm{~d} 5 / 2$ peak. The collected data were referenced to an energy scale with binding energies for $\mathrm{Cu}$ $2 \mathrm{p} 3 / 2$ at $932.67+/-0.05 \mathrm{eV}$, and $\mathrm{Au}$ at $84.0+/-0.05 \mathrm{eV}$. Low energy electrons and argon ions were used for specimen neutralization on insulating samples.

\subsection{UPS Measurements}

The UPS data were obtained on a Riken Keiki AC-2 photoelectron spectrometer. The samples and detector were placed in open air. The UV source was a deuterium $\left(\mathrm{D}_{2}\right)$ lamp with a spot diameter of $2 \mathrm{~mm}$ by $2 \mathrm{~mm}$. For the samples with a high efficiency of photoemission (the metals and graphite) the light source power was $49.9 \mathrm{nW}$, and for the samples with a low efficiency of photoemission (the polymers, coal, pyrite, and vitrinite) the light source power was $600.2 \mathrm{nW}$. The specified repeatable precision of the 
instrument is given as $0.02 \mathrm{eV}$. The samples were analyzed at a temperature of $22^{\circ} \mathrm{C}$, a relative humidity of $40 \%$, and a pressure of $1012 \mathrm{kPa}$.

\section{B. RESULTS}

\section{Effects of coal maceral composition on beneficiation}

Minimizing carbon loss to the negatively charged mineral refuse is critical to the success of electrostatic beneficiation. Losses may be attributed to organic particles having mineral inclusions not liberated during grinding prior to beneficiation, or perhaps in some cases, by the organic maceral particles that charged negatively. The comminution studies reported by King [6-8] showed that many pyrites remain entrained in macerals even when coal is ground to dimensions of a few tens of micrometers [6-8]. Therefore, the distribution and compositions of macerals and minerals influence both the efficiency of liberation and electrostatic separation.

Petrographic analyses of the charge-separated powders provide information on microstructural composition of the particles and its influence on beneficiation. The macerals of coal are of three major types: vitrinite, liptinite, and inertinite. Vitrinite, derived primarily from cellulose and lignin has the highest oxygen and also organic sulfur content of macerals [9]. Vitrinite is predominant, comprising 80 to 95 percent of the organic fraction in low rank coals. Liptinite, from fatty acid residues as found in cutine

and spores, is rich in aliphatic structures with greater hydrogen and lesser oxygen content than other macerals. Liptinite, chemically similar to amber, exhibits ultraviolet stimulated fluorescence properties in the optical microscope due to the existence of metastable excited electronic states. Carbon rich inertinite, which contains significant amounts of 
fised aromatic ring carbon structures, most resembles graphite. Inertutic is anong the more conductive macerals due to its clectron-delocalized pi bonding. Inertinite macerals often contain plant cell rennant cavifies, which habbor mineral inclustons.

If coal is ground into ultrafine particles, a large portion of the coal is reduced to particles consisting largely of individual macerals or minerals. Only when the minerals are physically liberated from minerals does it become possible to beneficiate coal before combustion. This limitation is present both for wet and dry pre-combustion cleaning. Since coal is pulverized down to -200 mesh $(\subset 75$ un) in an industrial power plant, the grinding process was linuted to this subrange. Petrographic analyses of electrostatically separated -200 mesh Hlinois No 6 coal powders showed that the plysical liberation and separation were boh inefficient. The results are sumunarized in Table 1. Fach number in Table 1 represents the number of particlas of each type as a percentage of all particles counted in the clean or refuse samples respectively.

Table I illustrates that lypinte and inertinite are emiched in the refuse whereas vitrinte is entriched in the dean fraction. There were many more mineral particles in the refuse portion than in the clean samples. There are many sources of error in the method used to identify particles comprised of both macerals and minerals, as given in Table 1. The small pyrtes were dificult to observe in the optical microscope, and the macerals, particularly inertinite, were not easily identifable. However particles of the three maceral dasses thenselves were readily distiaguishable from one another by microscopic inspection. 


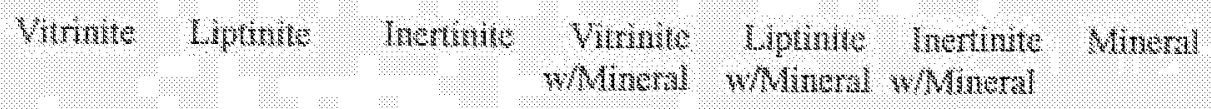

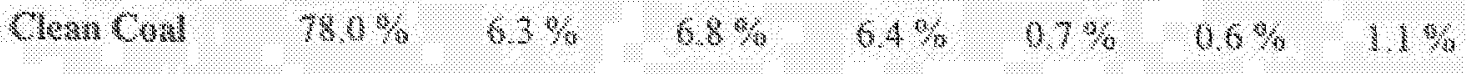

$\begin{array}{llllllll}\text { Refure Cour } \quad 66.1 \% & 105 \% & 92 \% & 5.3 \% & 1.4 \% & 0.6 \% & 69 \%\end{array}$

Table 1: Petrographic analyses of beneficiated IIInois No. 6 cod powders

The higher inertinite content in the refuse was confimed also by the technique of diffise reffectance infrared Fourier transform (DRIFT) spectroscopy. DRUFT spectra of powders from several benteficiation experments conducted with both Mhnois No. 6 and Pitsburgh No. 8 coal consistently exhibited a greater absorbance intensity for the aromatic ring vibration at a frequency of $1608 \mathrm{~cm}^{-1}$ for refuse in contrast to clean coul. Figure 4 (a) shows the DRIFT spectra of feed, and 4 (b) and 4 (c) shows the processed Pitsburgh No. 8 powders. The $1608 \mathrm{~cm}^{-1}$ absorption may be ascribed to inerinite based on the chemical composition of increased aromatic comtent for this maceral. The bands at 862,817 , and $751 \mathrm{~cm}^{-1}$, of the Figare 4 spectra correspond to defomation modes of aromatic ring strucures and appear to be of greater intensity in the spectrum of the clean fraction. However, this is not the case. Close inspection reveals that the shoulders of these bands are masked by mineral vibrations in the spectrum of the refise, but the vibrations are actukly of greater intensity than in the spectrum of clean coal. By petrography, others also have found a higher inertinite content in the negatiwely charged processod fraction from electrostatic beneficiation. Mineral indusions in the inertinite particles are a likely cause Similarly, the greater quantity of liptinite in the refuse nay be atributed to trapped 
minerals promoting a negative electrostatic tribocharge. Other salient features of the spectra in Figure 2 include: aliphatic C-H stretching 2800 to $3000 \mathrm{~cm}^{-1}$, aliphatic bending (deformation) at $1457 \mathrm{~cm}^{-1}$, and aluminosilicate mineral vibrations [11] at

$1034 \mathrm{~cm}^{-1}$ and $541 \mathrm{~cm}^{-1}$. The mineral bands are clearly largest in the refuse spectrum as expected. DRIFT spectra of Illinois No. 6 powders (not shown) illustrate a lower aliphatic C-H content than Pittsburgh No. 8 consistent with more oxidation present in the Illinois No. 6 coal as described below.

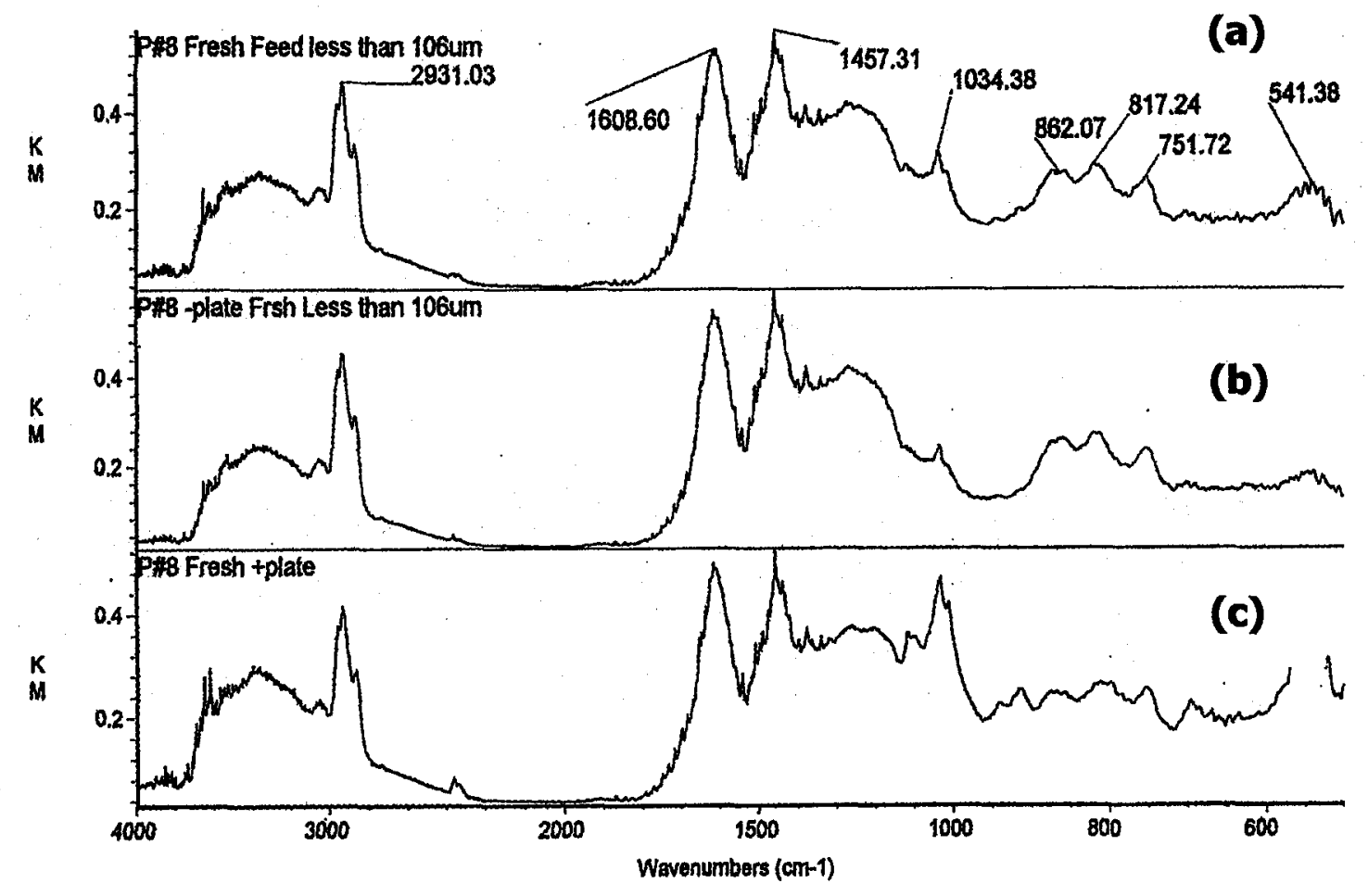

Figure 4: DRIFT spectra of (a) Pittsburgh No. 8 fresh feed coal, (b) processed No. 8 coal from the negative plate, and (c) processed No. 8 coal from the positive plate

The presence of increased quantities of inertinite and liptinite in the refuse is also reasonable considering the distribution of macerals and minerals in the coal matrix. Commonly, microscopic layers of homogeneous vitrinite bands are found to alternate with 
complex layers composed of all maceral types in bulk coal. The complex layers are appropriately named "trimacerite". The alternating microstructure results from the original plant deposits. Whereas bulk plant parts such as leaves and stems were converted to vitrinite during coalification, their surfaces were sullied with fine material from the environment. It is thus the interface of two plant part surfaces, which produced the complicated trimacerite. Bacterial action also prevailed on plant surfaces yielding increased pyrite in trimacerite in conjunction with increased inertinite and liptinite. Conversely, a greater abundance of vitrinite in the clean coal fraction is a reflection of low mineral content and expected preference to charge positively.

Charge-to-mass ratio data also indicate a more complex composition for the refuse relative to that of clean coal. Ranges in charge to mass values obtained from four separate beneficiation experiments conducted on each of three different size classified Pittsburgh No. 8 coal powders are shown in Figure 5 .

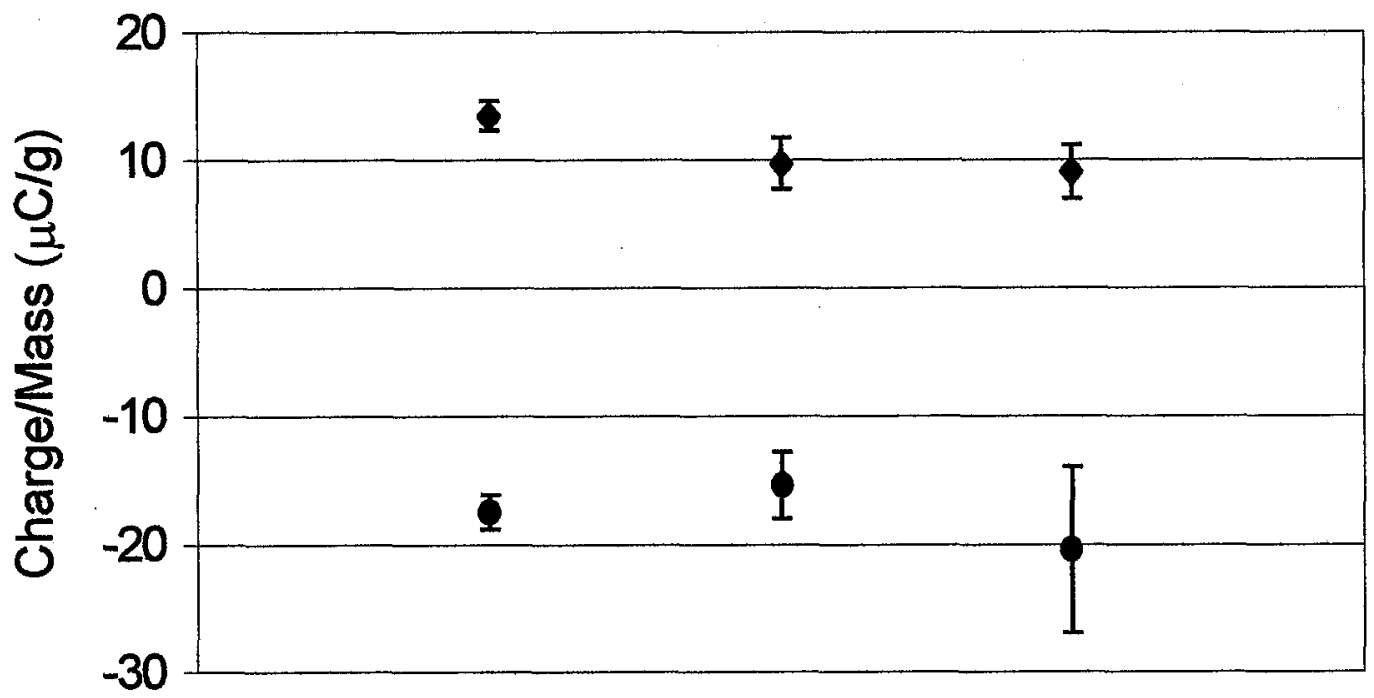


Figure 5: Charge to Mass Ratios for Pittsburgh No. 8 clean and refuse coal powders

As seen in Figure 5, variability in charge to mass ratios for the refuse was greater than for the clean coal for all three powder sizes. However, variability decreased with decreasing powder size. The smallest powder $(45-75 \mu \mathrm{m})$ showed the smallest average deviation for both the clean and refuse and also the highest positive value for the clean fraction. Therefore, finely ground coal exhibited improved dipolar charging character. Clean and refuse fractions of Illinois No. 6 coal exhibited lower degrees of charging than those of Pittsburgh No. 8. The average measured charge-to-mass ratios for Illinois No. 6 $(<75 \mu \mathrm{m})$ clean and refuse powders were $9.66 \mu \mathrm{C} / \mathrm{g}$ and $-12.6 \mu \mathrm{C} / \mathrm{g}$, respectively. These values are smaller than for the 45-75 $\mu \mathrm{m}$ powder fraction shown in Figure 5 and are consistent with the oxidized condition of the Illinois No. 6 sample.

\section{Effects of particle size and atmosphere on beneficiation}

Improved beneficiation is expected with fine grinding due to enhanced liberation of pyrite inclusions. Figure 6 shows the average total sulfur content of feed and beneficiated Pittsburgh No. 8 coal for two size classifications. 


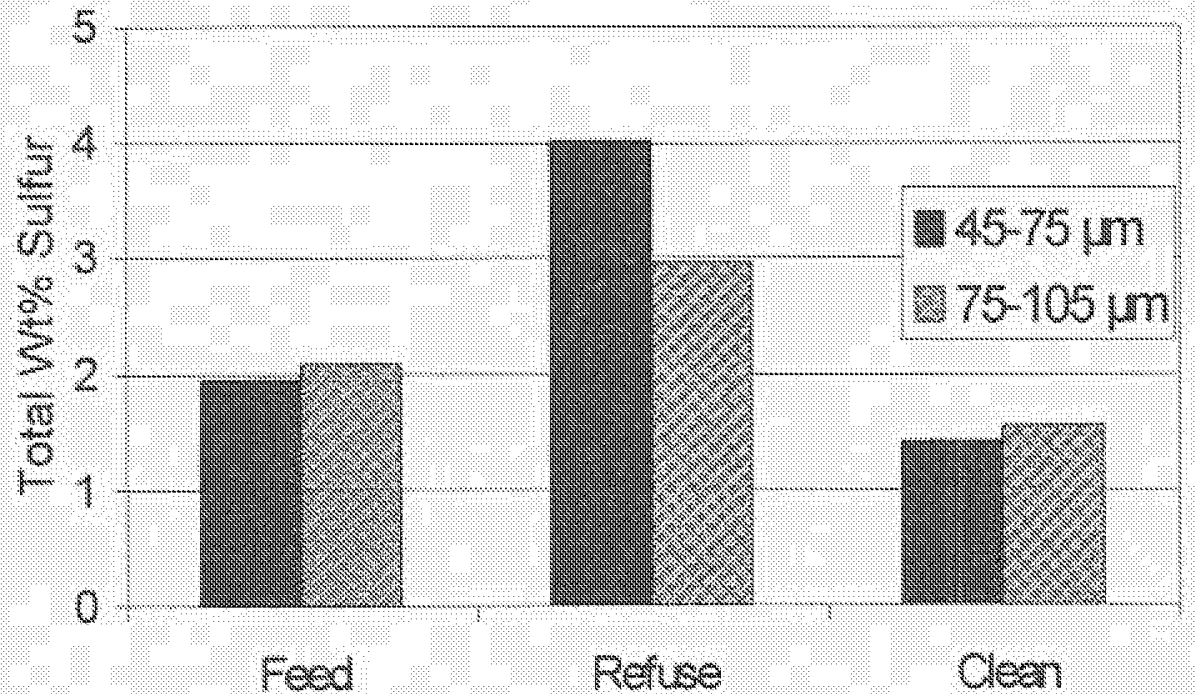

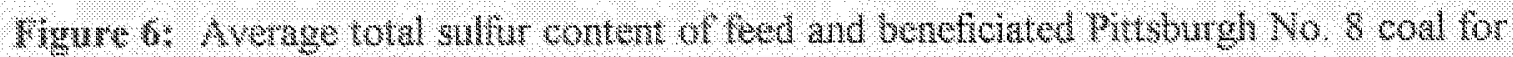
two stre classibcations

Rehuse from $45-75$ un powder was appreciably enrched in sullur tolative to that of 75-105 um powder and he cleaned 45-75 un powder had slyhty lower sultur contert. However, the percenage of feed recovered as clean was not mproved for the smaller sized powder. Spechically, the average mass percenages of dean coal reovered were $632 \%$ and $63 \% \%$ for the $45-754 m$ and $75-105$ ure powders respectively. Therdore. clean cod yeld was no inereased whi fine grinding. Howewer, the finer powder did yeld a therner conk

Surpringly, exposing Pitsburgh No. 8 con wo air for 24 kours atter grinding wnd prior to beneficktion did not adversely arect beneficiation. Average sulfur values lor air exponed Pitsburgh No 8 powders as shown in Figure 7 are comparable wo those of FGure

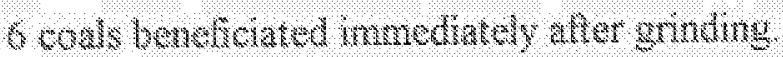




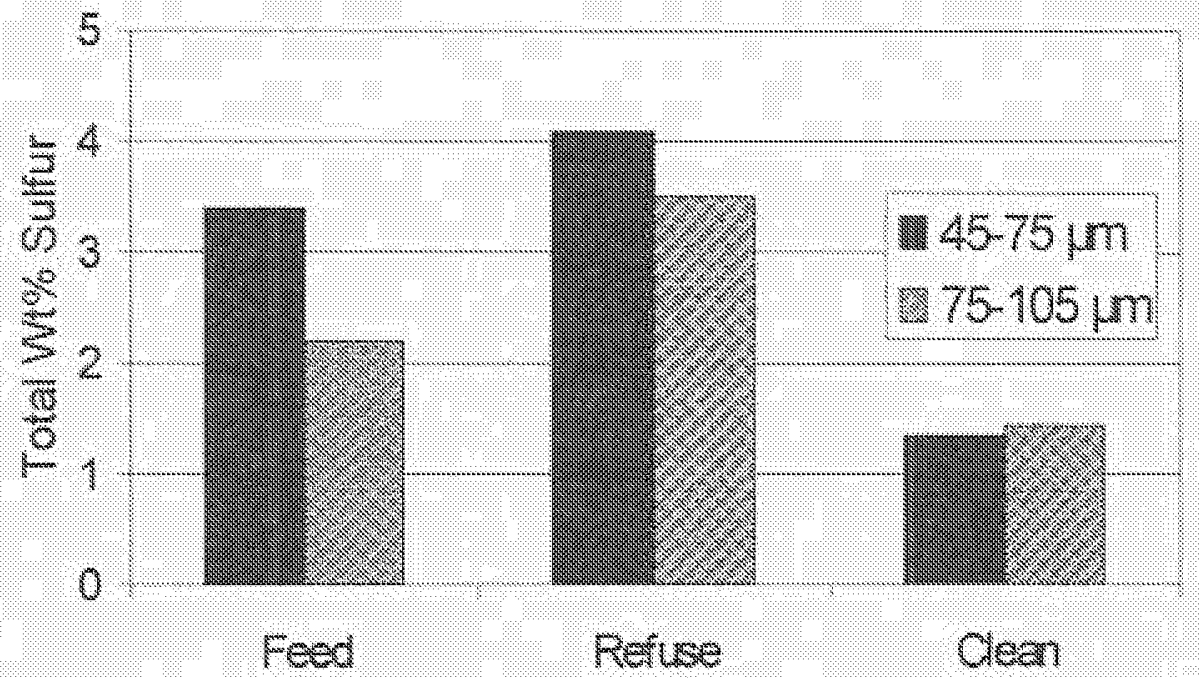

Figure 7: Average total sulfur content of Pitskburgh No. 8 coal powders processed after 24 hours of air exposure show similar beneficiation as that of fiesls ground powder.

Althowgh shon tern exposures of ground coal to air does not wignificantly degrade benefichation, oxidized coal in which an appreciable amount of the sullis is in the form of sulfate does not beneliciate well. The lot of Mhinois No. 6 coal used in this study was more oxidized than the Pitsburgh No. 8 . The eftects of oxidation are lilustrated in the data of

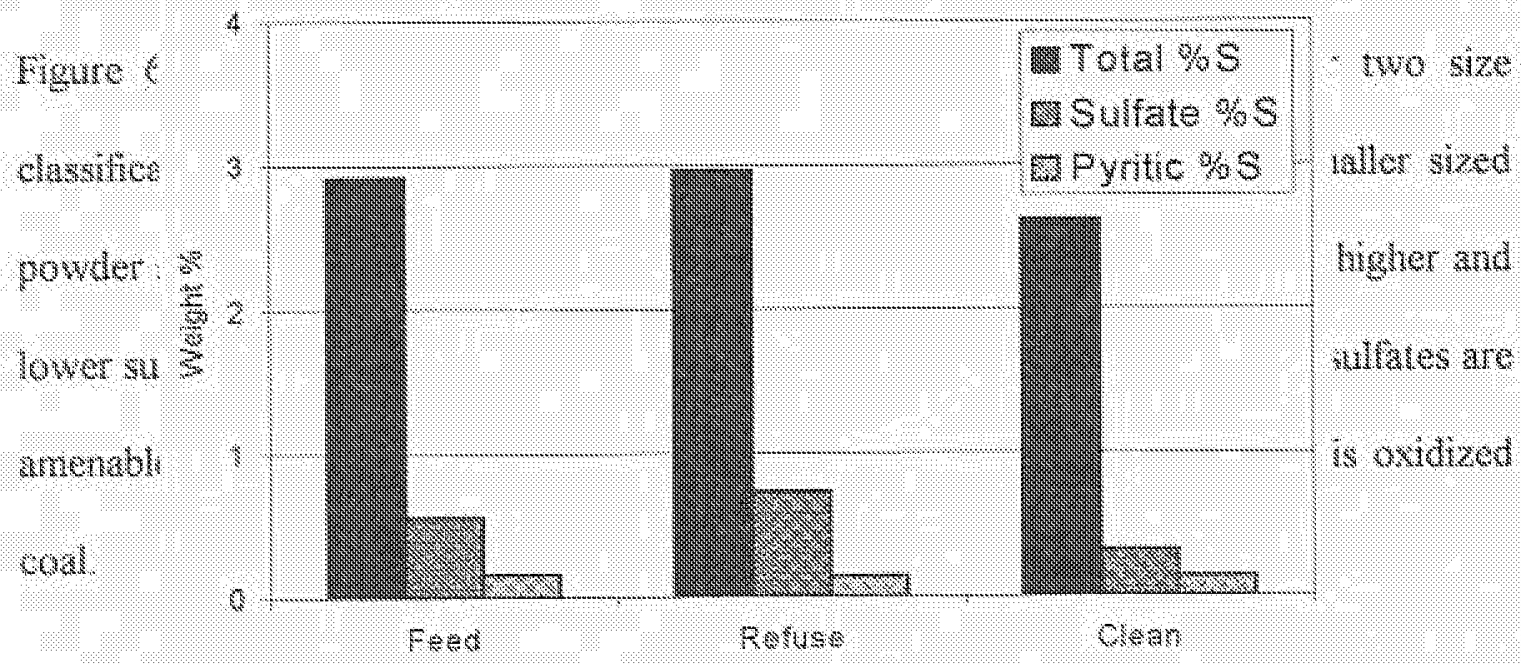


Figure 8: Effects of oxidation on Illinois No. 6 coal showing total sulfur, sulfate, and pyritic sulfur content for two size classifications.

The poor beneficiation of the oxidized Illinois No. 6 coal relative to that of the Pittsburgh No. 8 samples is dramatically shown in Figure 9 ash weight percentages obtained for powders of these coals. The Pittsburgh No. 8 refuse had a higher ash content than Illinois No. 6 even though the converse was true for the feed. It should be noted that these results do not demonstrate that Pittsburgh No. 8 is better than Illinois No. 6 for beneficiation, only that oxidized coal beneficiates poorly. 


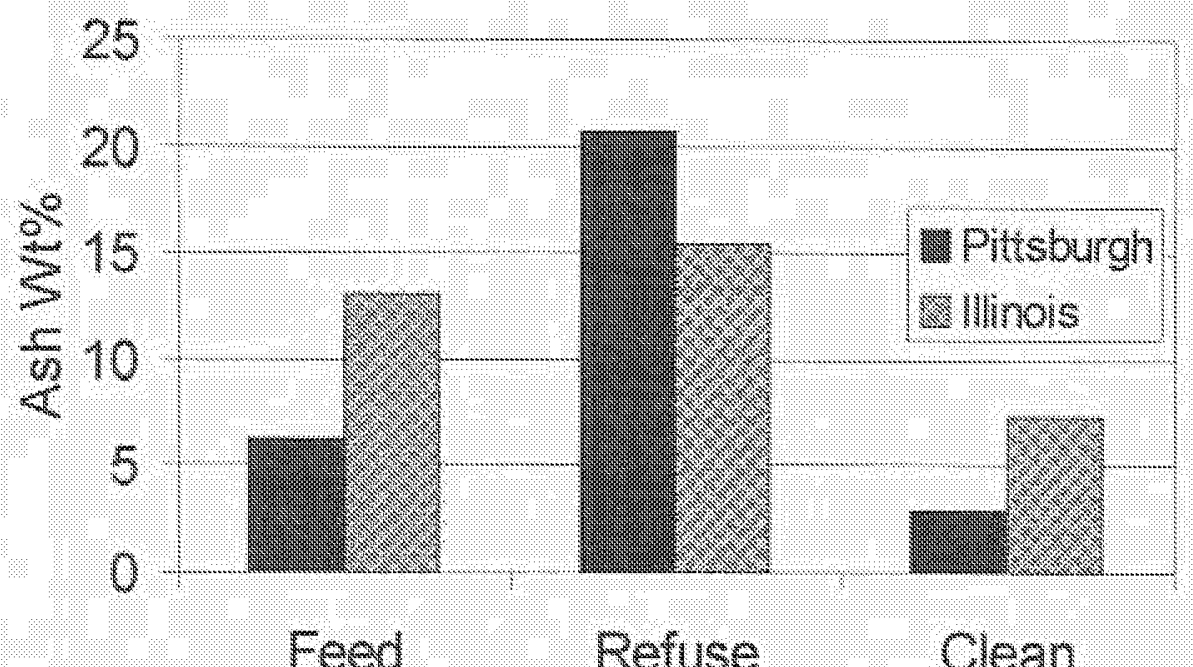

Figure 9: Ash percentages of Pitsburgh No. 8 and oxidized Mllinos No 6 coal powder showing poor beneficiation of oxdized thinom No 6 codt.

\section{Chects of conditioning agents on benefictation}

Conditioning agents to enhance beneficiation are preferably gaseous to prowide rapid and uniform treatment of coal powders. Both SO, and NH, function as chemical reducing agens and each was tested with the expectation inhibiting powder surface oxidation during benefictation. Acetone was chosen for study since ofiers had noted improvements in betreficlation using it as a conditioning agent [12]. The analytical results fiom the conditioning agent experiments using linnois No. 6 coal powders ane summarized in Figures 10 and 11 . 


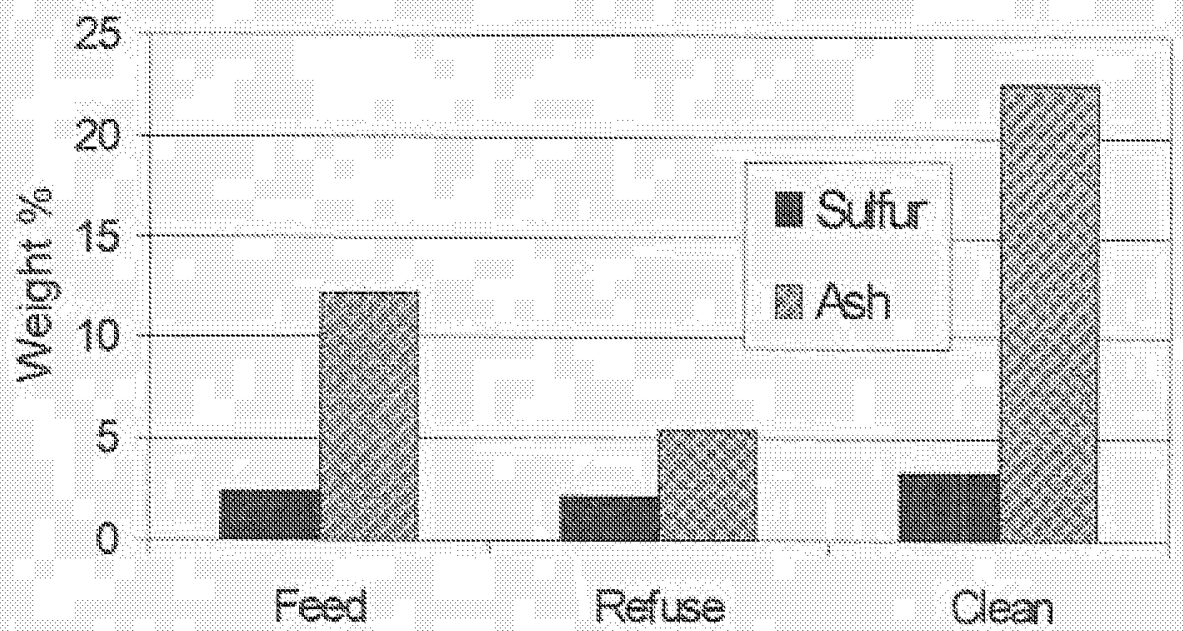

(a)

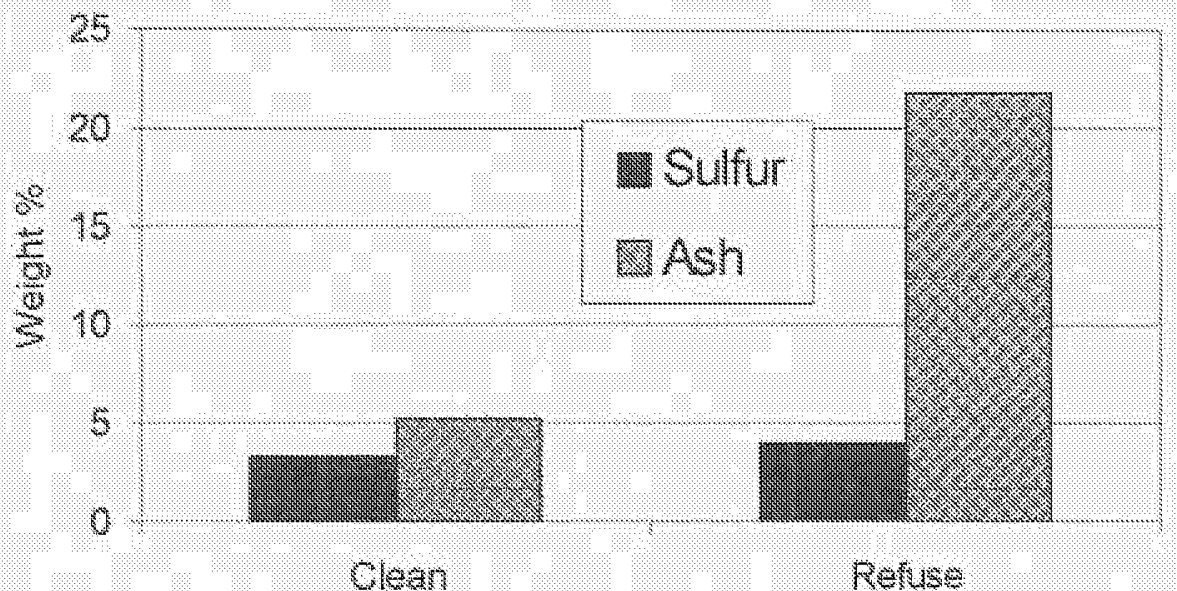

(1)

Figure 10, Resuts of 50 , condhoning agent experments with Wimois No. 6 powder showng control before exponure (a) and aher condivoning (b).

The data in figure 10 ilkurrate that 50 is not an eftective conditioning agent rnde the expermental conditions used. The percentage wultur and ash walues are bether for the control sarnple than for $\$ 0_{2}$ treated eorl. However, the awh contents were nearly the swe for both the treated and control powders indicating that adworbed SO, does not provide a pronounced detriment to beneficiuton of mineral content. Dath in Figure 11 
show that ammonia gas was actually detrimental to beneficiation perhaps as a result of increasing the hydrophilic properties of the coal powder. By contrast, beneficiation was slightly enhanced using acetone as conditioning agent. It should be noted that the Illinois No. 6 coal used for the conditioning agent experiments was from the same batch of coal as the oxidized Illinois No. 6 coal used for the data represented in Figures 8 and 9. However, the conditioning agent experiments were conducted two years prior and the high degree of oxidation was the result of two years storage of the coal.

\section{Second Pass Beneficiation Experiments}

Sulfur and ash analyses for 0-75 $\mu \mathrm{m}$ sized first and second pass Illinois No. 6 powders are shown in Figure 10.

The results in Figure 12 show that a second pass increases beneficiation. However, the clean coal fraction obtained after passing the refuse through a second time still is not as clean as the clean fraction obtained from the first pass.

Analytical results for $1^{\text {st }}$ and $2^{\text {nd }}$ pass experiments conducted with Pittsburgh No. 8 powders are shown in Figure 13. 

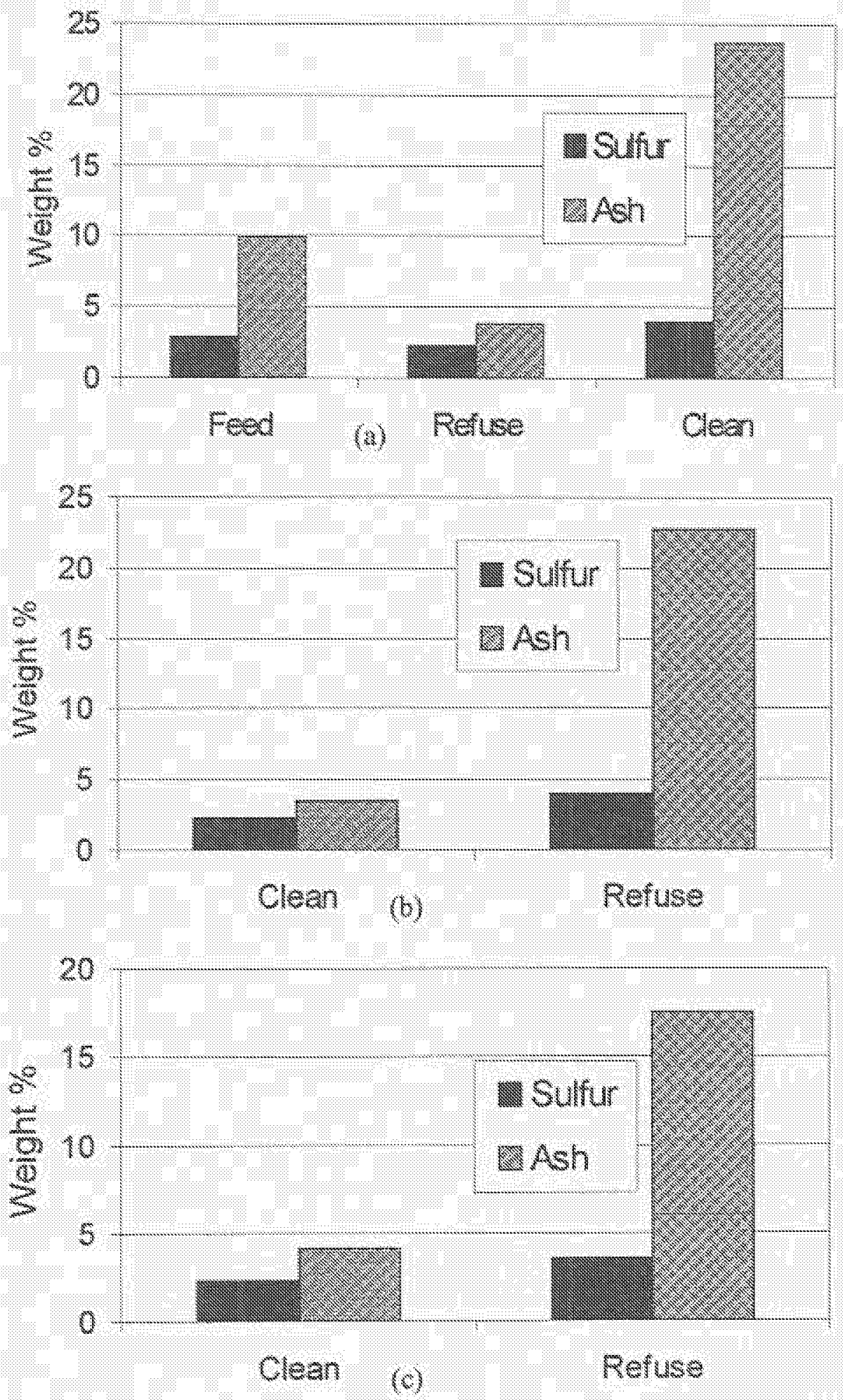

Figure 11: Results of conditioning agent experinents with Mlinois No. 6 powders showing control before exposure (a), acetone conditioning (b), and anmonia conditioning (c) 

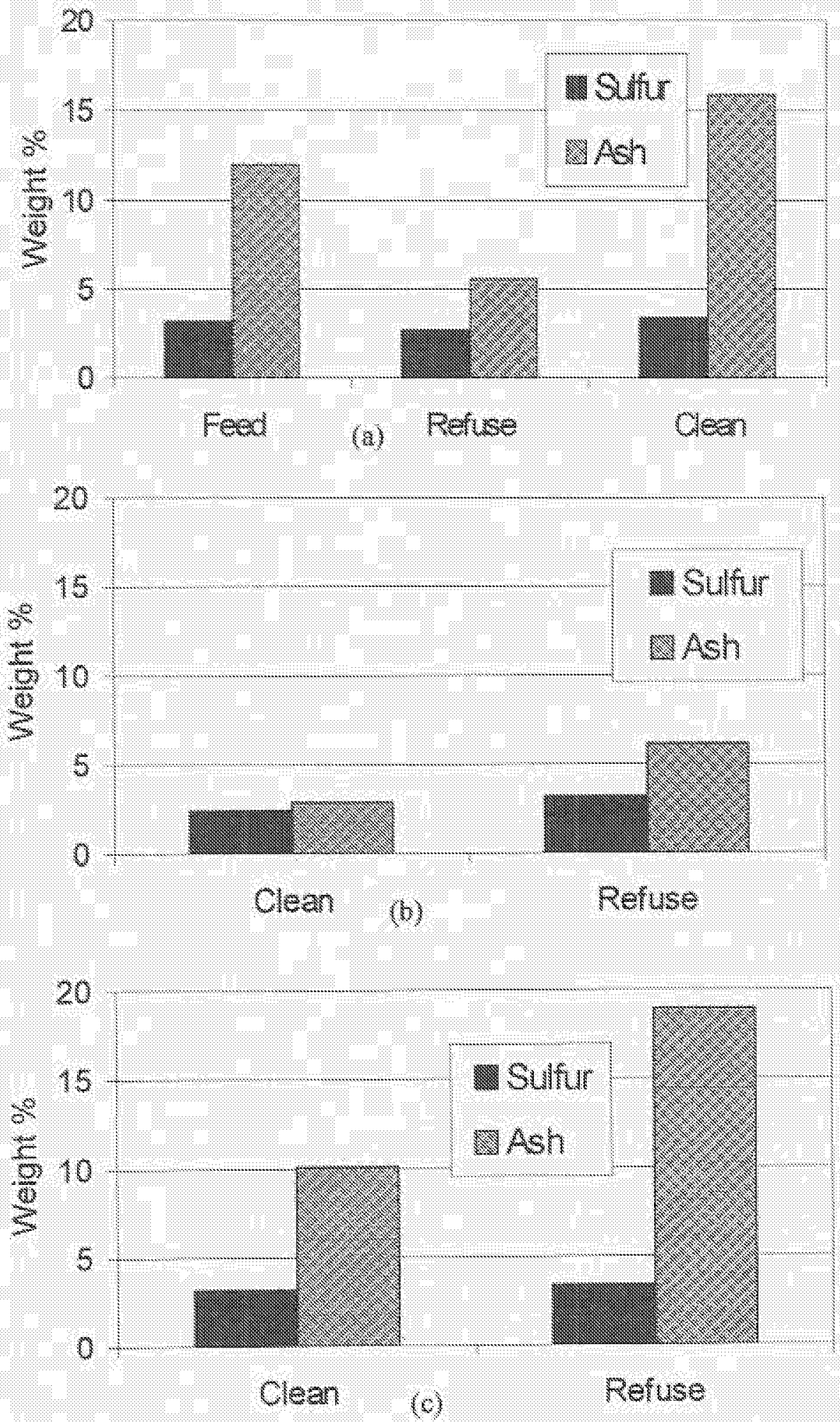

Figure 12: First pass ath and toral sultur values (a), and second pass ash and sulfir values for clean $(6)$ and refuse $(0)$ oxidized Minois No 6 powder. 

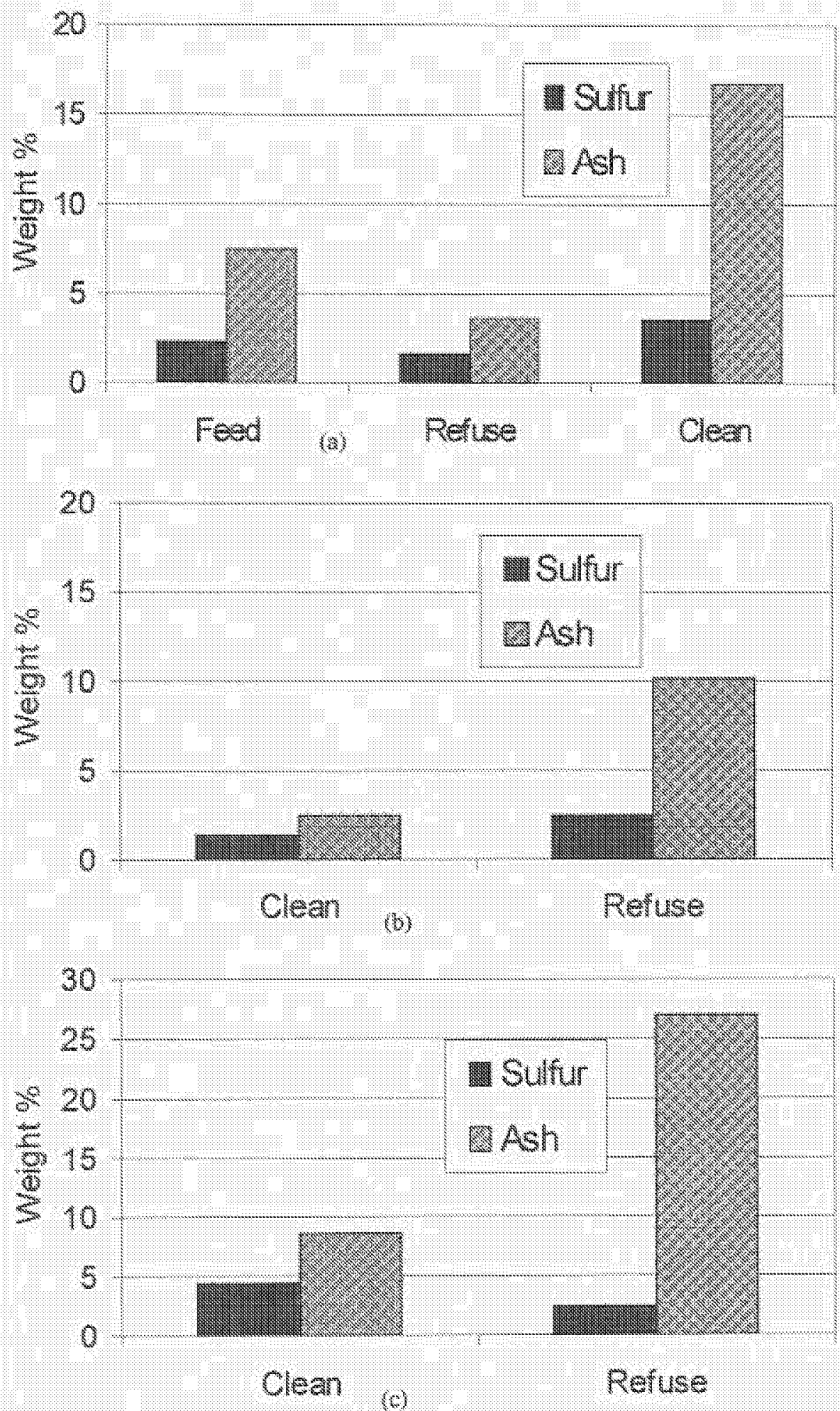

Figure 13: First pass ash and total sulfur values (a), and second pass ash and sulfur values for clean (b) and refuse (c) oxidized Pittsburgh No. 8 powder. 
The data from the two pass beneficiation is in agreement with the single pass data. Pittsburgh No. 8 is cleaned to a greater extent than Illinois No. 6. and ash forming minerals are more effectively removed than sulfur. The total sulfur content is not diminished in the clean fraction obtained when the first pass refuse is subjected to a second pass beneficiation. Moreover, for Pittsburgh No. 8 coal, this fraction actually contains more total sulfur than its corresponding refuse fraction as seen in Figure 11. How can this be? It appears that composite particles containing both pyrite and macerals are deposited in the refuse fraction from the first pass. When these composite particles then are subjected to a second pass beneficiation they adopt a positive electrostatic charge relative to the minerals present due to their maceral component. It is likely that interparticle collisions between minerals and composite particles during the second pass results in electron transfer from the maceral component of composite particles to mineral particles. The small dimensions of pyrite crystallites inhibits their effective liberation and separation from macerals and composite particles composed of pyrite and maceral may adopt either a positive or negative electrostatic charge depending on conditions.

The majority of coal from two-stage beneficiation of Pittsburgh No. 8 is recovered as clean coal. The percent recovered cumulatively from the negative plate of the separator from the first pass and second pass is $51.9 \mathrm{wt} . \%$ based on the mass of feed powder. The cumulative quantity of refuse from the positive plate was $13.1 \mathrm{wt} . \%$ and the quantity of coal collected on the filter at the bottom of the separator was $32.4 \mathrm{wt} . \%$. This leaves a remainder of $2.6 \mathrm{wt} . \%$ of total feed unaccounted for. 


\section{Effects of surface composition in tribocharging}

Tribocharging is the principle charging technique used in electrostatic beneficiation, and is achieved by exchanging charges between the pulverized coal particles and a charging material, in this case copper. The amount and polarity of the charge exchanged depends upon the relative work functions of the copper charger and the components of the powder. However, it is well documented that environmental factors such as humidity, contamination, chemi- and physi-adsorption can distinctly affect the work function of a surface $[4,13]$.

\subsection{UPS analysis}

The measured work functions of the cross-sectioned surface of the Illinois No. 6, Pittsburgh No. 8, and Kentucky No. 9 are shown in Table 2. The work functions were measured on a $2 \mathrm{~mm}$ by $2 \mathrm{~mm}$ spot at approximately $2 \mathrm{~mm}$ apart across each sample. Unfortunately due to charging in some areas on the surface, data from only two areas were obtained on the Illinois No. 6 sample. Remarkable consistency was observed across each sample, even though visible topographical differences were observed in the optical and Secondary Electron Microscopy (SEM) modes. However, the work functions measured for each coal specimen were significantly higher than that of $3.93 \mathrm{eV}$ as reported for coal samples by Inculet et al. ${ }^{10}$ The UPS measurements taken in air on the copper from an as-used Koflo static mixer, Polytetrafluroethylene (PTFE) which is also used as a tribocharging material, concentrated vitrinite from a double pass separation, pure pyrite, and graphite powder are shown in Table 3. 


\begin{tabular}{cccc}
\hline & & \multicolumn{2}{c}{ Coal sample work function [eV] } \\
Point & Illinois \#6 & Pittsburgh \#8 & Kentucky \#9 \\
\hline 1 & 5.40 & 5.41 & 5.44 \\
2 & 5.40 & 5.41 & 5.43 \\
3 & - & 5.42 & 5.43 \\
4 & - & 5.42 & 5.42 \\
5 & - & 5.42 & 5.46 \\
\hline
\end{tabular}

Table 2: Work function measurements on cross-sectioned coal samples in air

The UPS data shows the measured work functions for all samples to be higher than that reported for each sample in the literature with the exception of PTFE which is similar considering the experimental error of the technique $(+/-0.2 \mathrm{eV})$. The values reported in the literature were for clean pure specimens, and measured in vacuum. The data shown here clearly shows the influence of the environmental exposure on the work function of a surface in air. The measured work function for the vitrinite $(5.41 \mathrm{eV})$ is similar to that of the mean value for the coal specimens $(5.42 \mathrm{eV})$. As vitrinite has the highest oxygen concentration and is predominant in coal, this data suggests the surface of the coal cross-section specimens was predominantly vitrinite, rather than inertinite. Inertinite resembles graphite which was observed to have a measured work function of $5.09 \mathrm{eV}$. The most significant factor observed in this data is that the coal and pyrite had measured work functions $(5.42 \mathrm{eV}$ and $5.50 \mathrm{eV})$ higher than that for the copper from the 
static charger $(5.11 \mathrm{eV})$. This observation indicates that both the coal and pyrite particles would charge with negative polarity when tribocharged against copper in air, in contrast to the bipolar charging required for separation.

Material Measured work function Reported work function

Graphite

$5.09 \mathrm{eV}$

$4.50 \mathrm{eV}^{14}$

Copper

$5.11 \mathrm{eV}$

$4.38 \mathrm{eV}^{10}$

Concentrated Vitrinite

$5.41 \mathrm{eV}$

unknown

Coal*

$5.42 \mathrm{eV}$

$3.93 \mathrm{eV}^{10}$

Pyrite

$5.50 \mathrm{eV}$

$5.40 \mathrm{eV}^{10}$

PTFE

$5.80 \mathrm{eV}$

$5.75 \mathrm{eV}^{4}$

* Mean data from Table 2

Table 3: Work function measurements on various materials in air

\subsection{XPS analysis}

In the optical mode, distinct topographical bands were observed across the surface of each coal sample. One of the bands of the cross-sectioned surface of the Pittsburgh No. 8 coal is shown in an optical micrograph taken on the XPS spectrometer in Figure 14. The crack in the surface observed on the right of the micrograph was used for alignment purposes for the subsequent analysis. Two areas were analyzed, one in the band area, referred to as the rough area, and one in the smooth area adjacent to it. The XPS quantitative data is summarized in Table 4. 


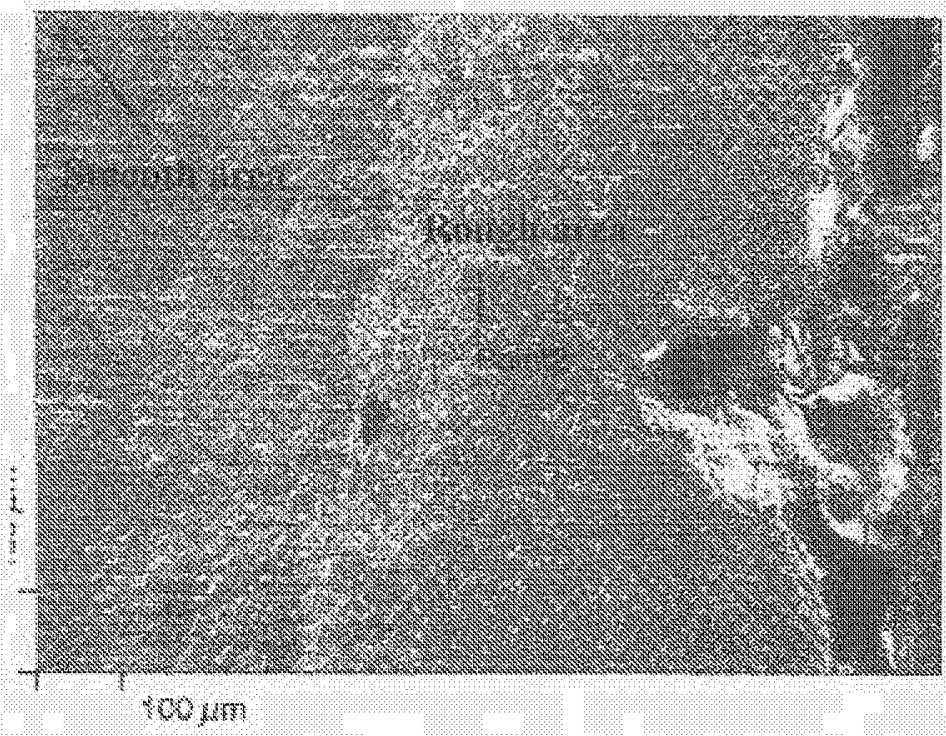

Figure 14: Ophical micrograph of he cross-sedwoned Phisburgh No s specimen showng the points of andyses

Anolysis area

Elenert (relkive ntomic percent ${ }^{\circ}$ )

$c$

O

$\$$

Fe

Smooth

844

134

0.4

118

Rousor

728

21.7

2.7

38

Twbie 4; XPs data for Pitwhurgh No 8 cod spromen

The data shows that he rough erea contuined higher concentrations ox oxygen, sulfu, and mon comparel wo the smooth area. Migh resolumon XPS soans of the carbon multur, and iron peaks of he rough and smoolh areas were taken to detemmine the oxact sumace

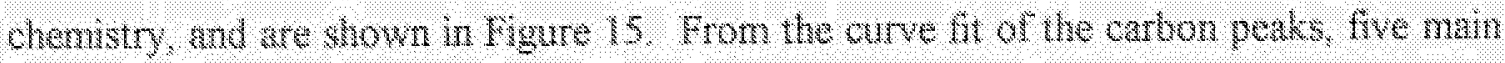


peak positions were measured at $284.6,286.2,286.5,288.0$, and $289.6 \mathrm{eV}$, which were identified as $\mathrm{C}, \mathrm{C}-\mathrm{O}, \mathrm{C}-\mathrm{S}_{2}, \mathrm{C}=\mathrm{O}$, and $\mathrm{O}-\mathrm{C}=\mathrm{O}$, bonding, respectively, based on that reported in the literature [15-18]. The data shows the carbon in both areas to be present as predominantly $\mathrm{C}-\mathrm{C}$ (or $\mathrm{C}-\mathrm{H}$ ) bonds. From the curve fit of the sulfur peaks, five main peak positions were measured at $162.5,163.9,165.7,168.2$, and $169.4 \mathrm{eV}$, which were identified as $\mathrm{FeS}_{2}, \mathrm{~S}-\mathrm{C}, \mathrm{S}_{\mathrm{n}}, \mathrm{SO}_{4}$, and $\left(\mathrm{SO}_{4}\right)_{3}$, bonding, respectively, based on that reported in the literature [15-18]. The data shows the sulfur to be present as predominantly in the sulfate form for both areas with only minimal sulfide $\left(\mathrm{FeS}_{2}\right)$ detected. However, on the smooth area, significantly more organic sulfur $(\mathrm{S}-\mathrm{C})$ and single sulfur bonds $\left(\mathbf{S}_{\mathrm{n}}\right)$ were detected than in the rough area, but the overall amount of sulfur detected was greater in the rough area (Table 4). From the curve fit of the iron peaks, four main peak positions were measured at $709.6,710.8,712.0$, and $713.1 \mathrm{eV}$, which were identified as $\mathrm{FeO}$, $\mathrm{Fe}(\mathrm{OH})_{3}, \mathrm{Fe}\left(\mathrm{SO}_{4}\right)_{\text {, and }} \mathrm{Fe}_{2}\left(\mathrm{SO}_{4}\right)_{3}$ bonding, respectively, with the peaks at 714.1 and 715.8 $\mathrm{eV}$ were identified as satellite peaks of the hydroxide and sulfate peaks, based on that reported in the literature [15-18]. The data shows the iron peaks to be present predominantly in the sulfate and hydroxide form, with a minor amount as oxide. No iron sulfide was detected in the iron peaks, although it was observed in the sulfur peaks. This may be just due to a difference in the escape depth of the photoelectrons from the sulfur peaks compared to the iron peaks. 


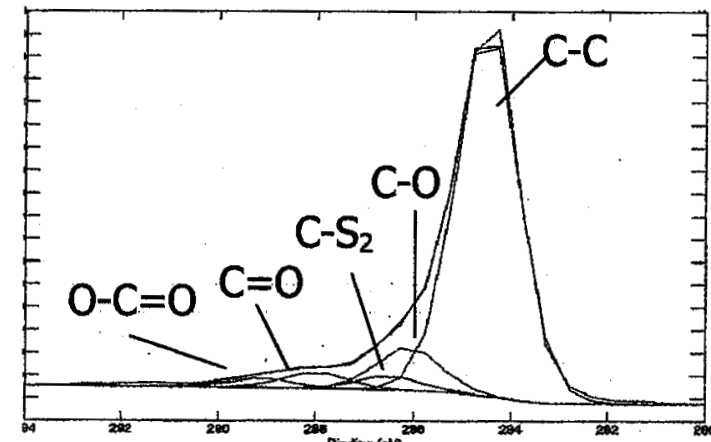

(a)

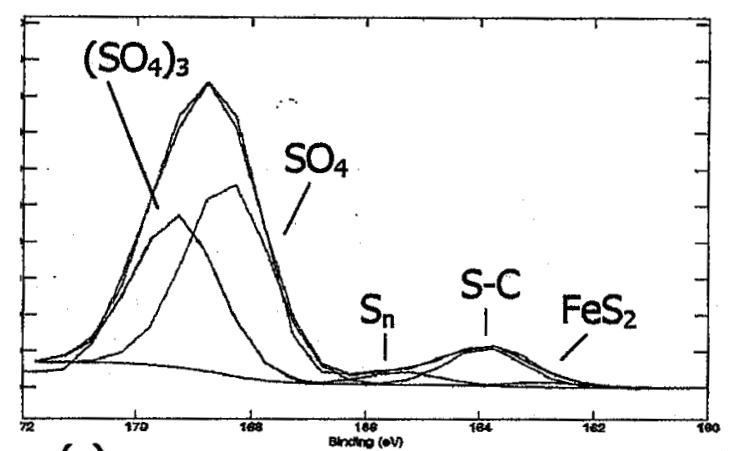

(c)

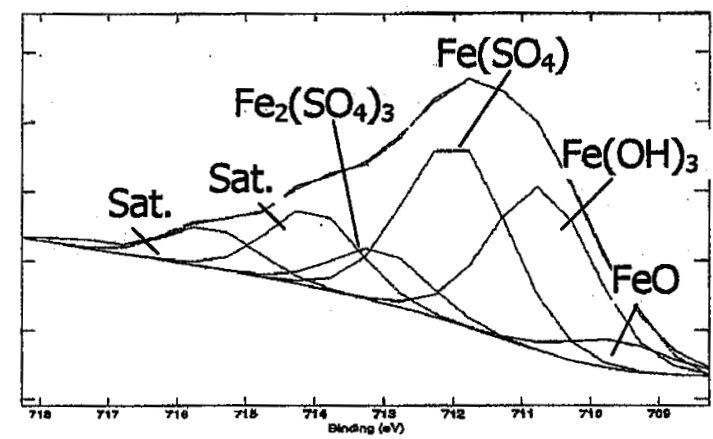

(e)

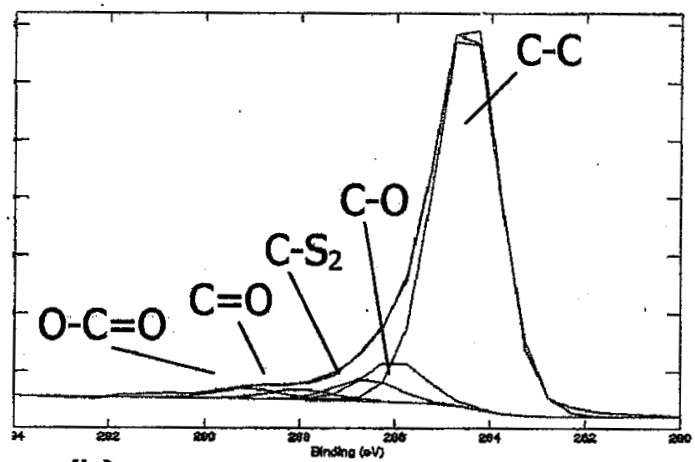

(b)
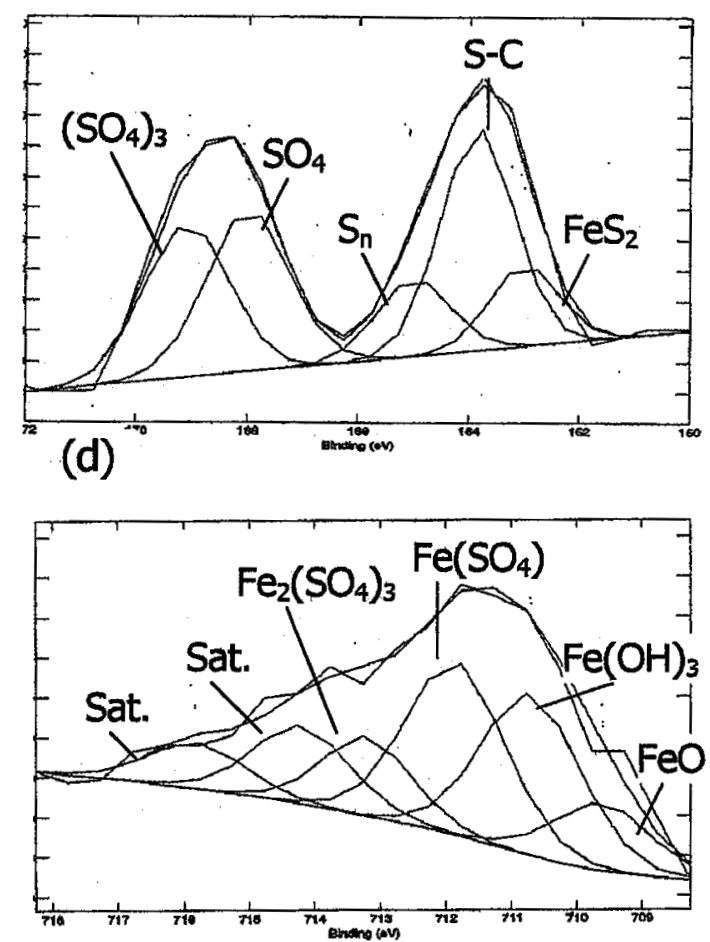

(f)

Rough Area

Smooth Area

Figure 15: XPS data for Illinois No. 6 coal sample showing: (a) and (b) $\mathrm{C} 1 \mathrm{~s}$, (c) and (d) S2p, and (e) and (f) Fe2p peaks for the rough and smooth areas 
Material

Element (relative atomic percent \%)

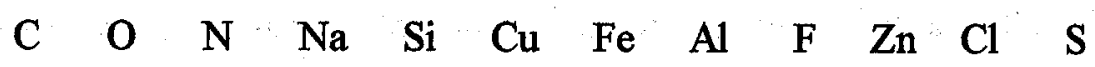

\begin{tabular}{|c|c|c|c|c|c|c|c|c|c|c|c|c|c|}
\hline Graphite & & 98 & 2.3 & --- & -- & $\cdots$ & --- & $\cdots$ & -- & -- & $\cdots$ & $\cdots$ & - \\
\hline Copper & 70 & 21 & -- & -- & 1.4 & 7.4 & -- & -- & -- & $\cdots$ & -- & -- & \\
\hline Vitrinite & & 68 & 25 & 1.1 & 0.3 & 2.9 & --- & -- & 2.4 & --- & --- & -- & 0.7 \\
\hline Pyrite & & 51 & 27 & -- & 0.6 & -- & --- & 5.4 & -- & -- & 0.4 & 1.4 & 14 \\
\hline TFE & & 30 & 0.2 & -- & -- & -- & -- & --- & $\cdots$ & 70 & -- & -- & \\
\hline
\end{tabular}

Table 5: XPS data for specimens analyzed in the as-received condition

The XPS data for the other materials is shown in Table 5. The data for the graphite shows it to be predominantly carbon, with only a minor amount of oxygen detected, which would indicate that pure carbon in the graphitic form does not oxidize to a great extent when exposed to air. The data for copper showed the metal had significant contamination on the exposed surface with only a minor amount of actual copper actually detected (7.4 atomic \%). This amount of contamination is typical for metals exposed to atmosphere. The vitrinite had a $\mathrm{C} / \mathrm{O}$ concentration ratio similar to that of the rough area on the coal sample, indicating this area was predominantly vitrinite. However, no iron showing the presence of pyrite was detected in the vitrinite sample. The pyrite sample showed a high concentration of carbon and oxygen, with only a minor amount of actual iron and sulfur observed (5.4 and 14 atomic \%) which correlates with the 
high resolution XPS data. PTFE has a chemical structure of repeat monomers of $-\mathrm{CF}_{2}$-, with a stoichiometry of carbon $33 \%$ and fluorine $66 \%$. The XPS data of PTFE showed a surface composition very close to that of the stoichiometry of the polymer. PTFE is known to resist oxidation, and this was shown in the XPS data. This would also explain why PTFE had a measured work function $(5.80 \mathrm{eV})$ similar to that reported in the literature $(5.75 \mathrm{eV})$.

\section{CONCLUSION}

In electrostatic beneficiation, coal was first pulverized and charged by contact with copper. The particles were then passed through an electrostatic separator consisting of two conducting electrodes, across which a high voltage was applied. Chemical analyses of total sulfur and ash content of feed and processed coals were used to evaluate the beneficiation success. It was determined that the efficiency of separation was dependent upon the coal particle composition, fineness of powder grind, and surface properties of the coal powder.

The petrographic analyses showed that the physical liberation and separation were both inefficient, but finely grounded coal did exhibit improve bipolar charging that improved the separation.

Fine grinding did not increase the clean coal yield, but did yield a cleaner coal. Exposure to air after grinding did not adversely affect beneficiation, except that oxidized coal in which an appreciable amount of sulfur was present as sulfate did not beneficiate well. It was found that $\mathrm{SO}_{2}$ was not an effective conditioning agent, $\mathrm{NH}_{3}$ was detrimental to beneficiation, but acetone did show slightly enhanced beneficiation. 
A second pass increased beneficiation in total, but the clean coal fraction obtained after passing the refuse through a second time was not as clean as the clean fraction obtained from the first pass.

Surface analyses of coal specimens and various related materials showed significant increases in the surface work function of certain materials which was dependent upon the amount of surface contamination and oxidation. Variations in the work functions between materials being charged in electrostatic separation may significantly affect the efficiency of beneficiation. In the case of coal beneficiation, the pulverized coal has been traditionally charged with a copper static mixer. The measured work functions of coal, pyrite, and copper were very close to each other. From these measurements, it appears that copper is perhaps not the best material for tribocharging pulverized coal due to the extreme similarities of the work functions of copper, coal macerals, and pyrite when exposed to air. Slight changes in environment and humidity can cause changes in the work functions values which may lead to the similar work function values of the coal macerals, pyrite, and copper alternating between positive and negative relative to each other. As a result, the charge distributions of macerals and minerals were bi-polar with a wide range. Ideally, a material with a work function whose value falls in between the work functions of coal macerals and pyrite needs to be used, and the data obtained in this study indicates polystyrene may be a good candidate under these conditions. However, polystyrene is a relatively soft material and the charging surface is likely to get covered with a thin layer of fine coal powder which will reduce the tribocharging efficiency. When choosing any material for tribocharging purposes, care must be taken in ensuring the actual surface work function is appropriate for the application and conditions of use. 


\section{RTENRTWCES}

1. Schicck R. Hanmant A. Fiechiet S. Konterkamp R. Wetrel H. Gectrical

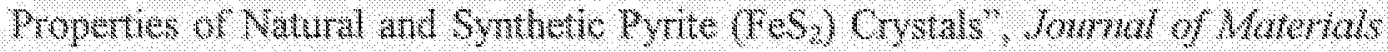
Rewerroh s. 1567-1572 (1990).

2. Li IX. Ban H. Hover JC. Stencel J M. Sato X, "Dry Triboclectrostate Separation of Mherd Particles a Potential Application in Space Froloration".

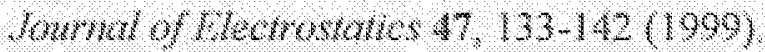

3. Iarsen I W. Flowers R.A. Hall P. Srbenagel B.G. Geblard L.A. in 1901

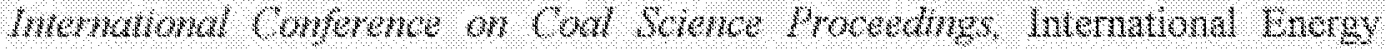
Ageno Coal Research L4, ed. (Butemorh Heinemann, Oxhrd), 1991 , pp, I-4

4. Cross 1. Mlectrostatics: Princinles, Problens and Apphication". (Adan Miger. Brisiol) 1987 (hapter?

5. Guo W. Findity and Thbochargity of Fine Powders". MS Theris, UALR (1909)

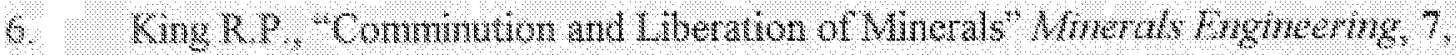
$120-140(1994)$

T. King R P. "Lnear Stochastie Models for the Aralysis of Mineral Liberation" Powder Techologe, $81,287-234(1994)$

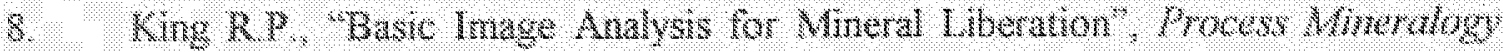
XWl, RO Magni ed. The Minerals, Metal, and Materals Soc. (Warrendale, Pencolvanid, 1095, op $145-157$

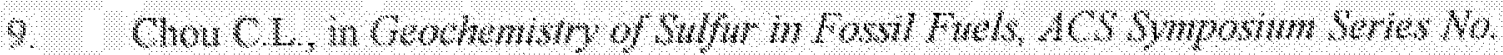

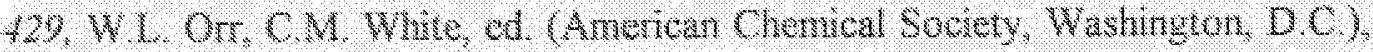
$1990,10 \% 31-52$

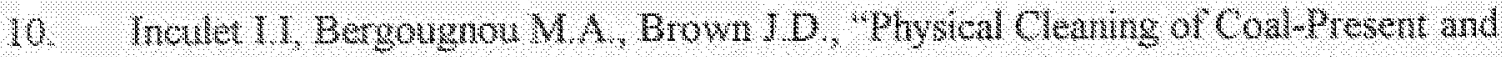
Developing Method:" Y A Lien ed (Warcell Dekker, WY ), 1982, po 87-131

11. Muni IM. Wisherd MP. Bonthan LC. "Intwred Absorpton Spectra of

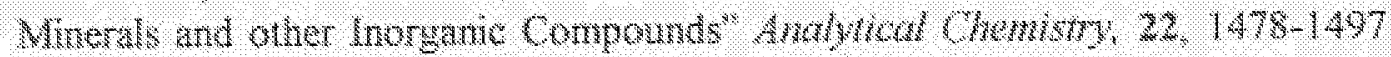
(1900)

12. Zhou G. Brown ID. "Cods Surace Condivining for Eewtrostatic Sepananon"

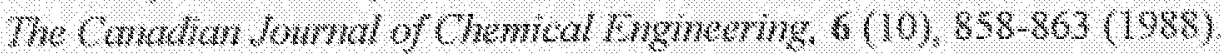


13. Lowell J., and Rose-Innes A.C., Advances in Physics, 29, pp. 947-1023, (1980)

14. Sauer D. and Stuve E.M., Changes in Work Function, http://www.mcallister.com/papers/stuve.html, 1999

15. Wagner C.D., Riggs W.M., Davis L.E., and Moulder J.F., "Handbook of XRay Photoelectron Spectroscopy", Ed. G.E. Mullenburg, Perkin-Elmer Corp., Eden Prairie, Minnesota, (1986)

16. Wagner C.D., Naumkin A.V., Kraut-Vass A., Allison J.W., Powell C.J., and Rumble J.R., "NIST X-roy Photoelectron Spectroscopy Database", NIST Standard Reference Database 20, Version 3.0 (Web Version), http://srdata.nist.gov/xps/, (2000)

17. Briggs D. and Seah M.P., "Practical Surface Analysis by Auger and X-ray Photoelectron Spectroscopy", John Wiley \& Sons, Chichester, England, (1983)

18. de Donato, P., Mustin, C., Benoit, R., and Erre, R., Applied Surface Science, 68, pp. 81-93, (1993) 